\title{
UVJETI DOPUŠTENOSTI POKRETANJA POSTUPKA PRED EUROPSKIM SUDOM ZA LJUDSKA PRAVA U STRASBOURGU
}

Dr. sc. Dinka Šago, docentica

Pravni fakultet Sveučilišta u Splitu
UDK: 341.174(4)EU

Ur.: 28. siječnja 2016.

Pr.: 21. ožujka 2016.

Pregledni znanstveni rad

\begin{abstract}
Sažetak
U ovom radu obrađeni su uvjeti dopuštenosti podnošenja zahtjeva Europskom sudu za ljudska prava s navođenjem pojedinih primjera, odnosno odluka o dopuštenosti koje je donio taj sud kako bi se pomoglo podnositeljima zahtjeva da, zbog formalnih propusta pri pokretanju postupka, ne izgube mogućnost ostvarivanja svojih prava pred tim sudom. Autorica nastoji ukazati na značaj mogućnosti pokretanja postupka pred tim sudom za ostvarivanje temeljnih ljudskih prava i sloboda građana Republike Hrvatske. Uvjeti dopuštenosti podnošenja zahtjeva propisani su čl. 33., čl. 34. i čl. 35. Europske konvencije za zaštitu ljudskih prava i temeljnih sloboda. Većina se zahtjeva odbacuje upravo zbog neispunjavanja tih uvjeta. Ispitivanje dopuštenosti često je odlučujuće za sudbinu zahtjeva, tim više što se odluka o nedopuštenosti ne može ni na koji način pobijati.
\end{abstract}

Ključne riječi: Europska konvencija za zaštitu ljudskih prava i temeljnih sloboda, Europski sud za ljudska prava, zahtjev, uvjeti dopuštenosti.

\section{UVOD}

Europska konvencija za zaštitu ljudskih prava i temeljnih sloboda (Konvencija) ${ }^{1}$ štiti građanska i politička te ekonomska i socijalna prava. Europska konvencija za zaštitu ljudskih prava i temeljnih sloboda potpisalo je u Rimu 4. studenoga 1950. godine dvanaest država članica novoosnovanog Vijeća Europe, a na snagu je stupila 3. rujna 1953. godine. Odredbe Konvecnije nekoliko su puta nadopunjavane dodatnim protokolima. Sve države članice Vijeća Europe stranke su Konvencije

1 Europska konvencija za zaštitu ljudskih prava i temeljnih sloboda, Međunarodni ugovori 18/97, 6/99, 14/02, 13/03, 9/05, 1/06, 2/10. 
te se od novih članica Vijeća zahtijeva njena ratifikacija. Hrvatska je Konvenciju i njene protokole ratificirala 5. studenoga 1997. godine postavši tako 40. država koja je to učinila.

Nadležnost Europskog suda za ljudska prava (ESLJP) proteže se na sve predmete glede tumačenja i primjene Konvencije i dodatnih protokola kao što su pojedinačni zahtjevi i međudržavni sporovi. ESLJP može razmatrati samo zahtjeve koji se odnose na povredu jednog ili više prava navedenih u Konvenciji i protokolima. Zahtjevi za pokretanje postupka u kojima se traži zaštita prava koje nije utvrđeno Konvencijom ili se ne može podvesti pod neku od odredbi Konvencije ili njenih protokola Sud će odbaciti kao nespojive ratione materiae.

ESLJP nije prizivni sud u odnosu na domaće sudove te ne može poništiti ili izmijeniti njihove odluke. ${ }^{2}$ Visoke se ugovorne stranke obvezuju da će se podvrgnuti konačnoj presudi Suda u svakom sporu u kojem su stranke. Konačna presuda Suda dostavlja se Odboru ministara, koji nadzire njezino izvršenje. ${ }^{3}$ Ako ESLJP ustanovi navedenu povredu, vratit će slučaj Odboru ministara kako bi razmotrio mjere koje treba poduzeti, a ako ustanovi da povrede nema vratit će slučaj Odboru ministara koji će zaključiti ispitivanje slučaja.

Sud može, na zahtjev Odbora ministara ${ }^{4}$, davati savjetodavna mišljenja o pravnim pitanjima glede tumačenja Konvencije i dodatnih protokola. Takva se mišljenja ne smiju odnositi na pitanja vezana uz sadržaj ili domašaj prava i sloboda određenih u odjeljku I. Konvencije ${ }^{5}$ i dodatnim protokolima, ili na bilo koje drugo pitanje koje bi ESLJP ili Odbor ministara mogli razmatrati na temelju nekog postupka koji je započeo u skladu s Konvencijom.

2 Vidi Omejec, J., Primjena Konvencije za zaštitu ljudskih prava i temeljnih sloboda u radu domaćih sudova, I. dio, Hrvatska pravna revija, rujan 2007., str. 3.

3 Ako Odbor ministara smatra da je nadzor nad izvršenjem konačne presude otežan nekim pitanjem tumačenja vezanim uz tu presudu, Odbor može predmet uputiti Sudu da odluči o tom pitanju. Odluka Odbora o upućivanju donosi se dvotrećinskom većinom predstavnika ovlaštenih sudjelovati u radu Odbora. Ako Odbor ministara smatra da se neka visoka ugovorna stranka odbija podvrgnuti konačnoj presudi u sporu u kojemu je stranka, Odbor može nakon službene obavijesti toj stranci, odlukom usvojenom dvotrećinskom većinom predstavnika ovlaštenih sudjelovati u radu Odbora, uputiti ESLJP-u pitanje je li ta stranka propustila ispuniti svoje obvezu, odnosno podvrći se konačnoj presudi ESLJP-a u svakom sporu u kojem je stranka.

4 Odluke Odbora ministara da od ESLJP-a traži neko savjetodavno mišljenje donose se većinom glasova predstavnika koji imaju pravo djelovati u Odboru.

5 Pravo na život; zabrana mučenja; zabrana ropstva i prisilnog rada; pravo na slobodu i sigurnost; pravo na pošteno suđenje; nema kazne bez zakona; pravo na poštovanje privatnog i obiteljskog života; sloboda mišljenja, savjesti i vjeroispovjesti; sloboda izražavanja; sloboda okupljanja i udruživanja; pravo na brak; pravo na djelotvoran pravni lijek; zabrana diskriminacije. 


\section{UVJETI ZA PRISTUP SUDU}

ESLJP-u mogu se obratiti bilo koje osobe ili grupe osoba koje smatraju da im je neka od država koje su prihvatile Konvenciju uskratila neko od prava koja su tom Konvencijom zajamčena. Svoje prigovore prema nekoj od država podnositelji upućuju ESLJP-u u obliku pismenog zahtjeva, čime započinje postupak pred ESLJP -om. Pravila postupka uređena su Poslovnikom Suda i Konvencijom.

Da bi se pojedinci mogli obratiti ESLJP-u i zatražiti zaštitu ljudskih prava i temeljnih sloboda, potrebno je kumulativno ispuniti sljedeće pretpostavke: povrijeđeno je ljudsko pravo ili temeljna sloboda zaštićena Konvencijom ili dodatnim protokolima; povreda je učinjena odlukom javne vlasti; iscrpljena su sva pravna sredstva koja pruža državni poredak države članice (u protivnom će biti odbačena, Konvencija čl. 35. st. 1.); ako protiv pravomoćne presude postoji domaći pravni lijek, podnositelji zahtjeva mogu doći pred ESLJP tek po iscrpljivanju domaćih pravnih sredstava $a^{6}$ zaštitu je iznimno moguće dobiti i ako nije iscrpljen cijeli domaći pravni put, ako postoji povreda prava na pošteno suđenje, primjerice ako sud nije odlučio u razumnom roku; da se osoba koja zahtijeva otklanjanje povrede obratila ESLJP unutar predviđenog prekluzivnog roka od 6 mjeseci od konačne domaće odluke.

Država je dužna: a) zaustaviti povredu Konvencije in concreto; b) popraviti posljedice povrede (najčešće novčanom naknadom, obnova postupka) ${ }^{7}$; c) spriječiti ponavljanje sličnih povreda, ako treba i izmjenom zakonodavstva.

ESLJP može dosuditi pravičnu naknadu, ali za to moraju biti ispunjene određene pretpostavke: a) utvrditi povredu nekog od prava zaštićenih Konvencijom; b) mora postojati oštećenik; c) unutarnje pravo države omogućuje samo djelomičnu naknadu za posljedice povrede Konvencije utvrđene presudom; d) pravična naknada mora biti nužna (čl. 41. Konvencije). ${ }^{8}$

6 Kudla v. Poland [GC], no. 30210/96, ECHR 2000-XI.

7 Svako traženje pravične naknade treba iznijeti u pisanom očitovanju o osnovanosti zahtjeva, ili ako takvo pismeno očitovanje nije podneseno u posebnom dokumentu koji se podnosi najkasnije dva mjeseca nakon donošenja odluke o dopuštenosti zahtjeva. Tijekom postupka vijeće može pozvati svaku stranku da podnese primjedbe na traženje pravične naknade. U pravilu, podnositelji već pri podnošenju zahtjeva u njega uključuju i potraživanje naknade. ESLJP će pravičnu naknadu smatrati neophodnom onda kada postoji uzročna veza između pretrpljene štete i povrede Konvencije. Šteta koja je nastala iz drugih razloga, premda povezana s povredom, ne uzima se u obzir. Primjerice, u predmetu Quranta protiv Švicarske ESLJP je ustanovio povredu prava zajamčenog čl. 6. st. 2. u odnosu na podnositelja (pravo na besplatnog branitelja). Podnositelj je tražio naknadu materijalne štete zbog vremena provedenog u zatvoru. ESLJP je, međutim ustanovio da ne postoji uzročna veza između počinjene povrede i počinjene materijalne štete zbog boravka u zatvoru. Iako ESLJP nije detaljno obrazlagao svoj stav izgleda da je prihvaćen argument tužene države da se ne može tvrditi da bi ishod postupka za podnositelja bio povoljniji da mu je bila dodijeljena besplatna pravna pomoć. Vidi Cvrčić, R., Djelovanje Europskog suda za ljudska prava s osvrtom na presude protiv Republike Hrvatske, Hrvatska pravna revija, 2003., br. 2., str. 9-10.

8 Kad postoji uzročna veza između pretrpljene štete i povrede Konvencije, npr. ako mu nije dodijeljen besplatni branitelj. 


\section{NADLEŽNOST SUDA RATIONE PERSONAE}

Personalni kriterij daje odgovor na pitanje tko ima aktivnu legitimaciju odnosno tko se može obratiti ESLJP-u kao podnositelj predstavke (aplikant). Postupak pred Sudom mogu pokrenuti fizičke osobe, nevladine organizacije ili skupine pojedinaca koji tvrde da su žrtve povrede prava priznatih u Konvenciji ili njenim dodatnim protokolima koje je počinila neka od država ugovornica (čl. 34. Konvencije), kao i države ugovornice povodom navodne povrede neke odredbe Konvencije ili njenih protokola, koju je počinila neka druga država (čl. 33. Konvencije). Visoke ugovorne stranke obvezuju se da ni na koji način neće sprječavati djelotvorno vršenje toga prava.

Pri podnošenju zahtjeva podnositelje mogu, ali i ne moraju zastupati kvalificirai punomoćnici. Podnositelje može zastupati bilo koji odvjetnik registriran u bilo kojoj državi ugovornici. Odvjetnici bi morali voditi računa o tome da ESLJP ne priznaje aktivnu legitimaciju umrlim osobama, ${ }^{9}$ pa će stoga svaki zahtjev podnesen u ime umrle osobe, na temelju punomoći koju je ta osoba za života dala odvjetniku, biti odbačen. Dakle, ESLJP razlikuje situaciju u kojoj je podnositeljevom nasljedniku dopušteno ustrajati u zahtjevu koji je već pokrenut od situacije u kojoj bi nasljednik ustrajao u zahtjevu podnesenom u ime pokojnika jer pokojnik, zapravo nikad i nije sudjelovao u postupku pred ESLJP-om. ${ }^{10}$ Takvim postupanjem nanosi se šteta nasljednicima umrle osobe koji bi, ovisno o tome radi li se o prenosivom pravu, mogli biti aktivno legitimirani na podnošenje vlastitog zahtjeva. ${ }^{11}$

ESLJP će zahtjev za pokretanje postupka proglasiti nedopuštenim zbog nespojivosti ratione personae s odredbama Konvencije u nekoliko slučajeva, ako zahtjev nije podnesen protiv države, već protiv neke organizacije ili pojedinca unutar države. Međutim, ESLJP smatra da se država ne može osloboditi svojih obaveza i odgovornosti prebacivajući ih na privatne institucije ili pojedince i na

9 Vidi odluku Dupin protiv Hrvatske, br. 3686/03. Zahtjev se ne može podnijeti u ime preminule osobe, budući da preminula osoba nije u mogućnosti, pa niti putem punomoćnika, podnijeti zahtjev Sudu (vidjeti Yaşa protiv Turske, br. 22495/93, izvješće Komisije od 8. travnja 1997., st. 88, Izviješća o presudama i odlukama 1998. VI). S obzirom na to da je neosporno da je g. Vladimir Dupin umro više od sedam mjeseci prije nego što su njegovi punomoćnici podnijeli zahtjev u njegovo ime, proizlazi da predmet nije pokrenula osoba koju se može smatrati podnositeljem zahtjeva u svrhu čl. 34. Konvencije (vidjeti, mutatis mutandis, Post protiv Nizozemske (odl.), br. 21727/8, od 20. siječnja 2009). Stoga je postojeći zahtjev, s obzirom na g. Vladimira Dupina, nedopušten ratione personae u skladu s odredbama Konvencije u smislu čl. 35. st. 3. te mora biti odbačen temeljem čl. 35. st. 4. (vidjeti Gavrielidou i drugi protiv Cipra (odl.), br. 73802/01, od 13. studenog 2003, Gürleşen i drugi protiv Turske (odl.), br. 15573/03, od 29. travnja 2008, Eşkikara i drugi protiv Turske (odl.), br. 45095/05, od 21. listopada 2008., Kaya i Polat protiv Turske (odl.), br. 2794/05, 40345/05, od 21. listopada 2008.).

10 Vidjeti Poznanski protiv Njemačke (odl.), br. 25101/05, od 3. srpnja 2007. i, mutatis mutandis, Karagiannis i drugi protiv Grčke (revizija), br. 51354/99, st. 10, od 8. srpnja 2004.

11 Vidi Maričić, D., Aktivna legitimacija za podnošenje zahtjeva Europskom sudu za ljudska prava, Hrvatska pravna revija, god. I., broj 8., str. 117-120. 
taj način onemogućiti pokretanje postupka zbog povrede prava pred ESLJP-om. ${ }^{12}$ ESLJP će zahtjev za pokretanje postupka proglasiti nedopuštenim ratione personae ako je zahtjev podnesen protiv države koja nije ratificirala Konvenciju ili protokole uz nju, kao i u slučajevima u kojima podnositelj zahtjeva nema status žrtve.

Svaka država može se naći pred Sudom kao tužena država samo za povrede EK počinjene nakon njenog pristupanja EK, a nikako za povrede učinjene ranije. Za povrede ljudskih prava učinjene prije pristupanja EK, oštećeni svoja prava može ostvariti samo pred nacionalnim institucijama, na način predviđen domaćim zakonima. ${ }^{13}$ To znači da se ne može podnijeti protiv države koja nije članica EK, a niti protiv neke fizičke ili druge pravne osobe. ${ }^{14}$

\subsection{Državne predstavke}

Osnovna intencija EK koja je izražena u Preambuli, je u tome da se ostvare jamstva za primjenu ljudskih prava koje sadrži. Riječ je o tzv. «kolektivnoj garanciji». U tom smislu su države koje su potpisale obvezu da će poštovati ljudska prava i da će prihvatiti «kolektivnu garanciju» pozvane da ukažu na svaku povredu ljudskih prava koju čini bilo koja druga članica EK. Ovdje je država pozvana da pokrene postupak za zaštitu ljudskih prava pred Sudom bez obzira o kojoj se državi radi i bez obzira radi li se o njenim državljanima ili državljanima drugih država. Preduvjet mogućnosti podnošenja tužbi u rneđudržavnim sporovima je ratifikacija EK od strane svih država koje su u sporu te država ne mora dokazivati niti imati pretpostavljeni posebni interes u sporu koji pokreće. Na ovaj način vidljivo je da između države koja podnosi predstavku Sudu i pojedinca kojem su navodno povrijeđena određena prava iz EK, ne mora postojati veza državljanstva. U tom smislu, riječ je o actio popularis kojom države pokreću sporove bez obzira na to kojoj državi pripada pojedinac čija su ljudska prava ugrožena. Na ovaj način se negira princip nemiješanja u poslove drugih država u unutrašnju domenu.

Prema čl. 33. EK sve države potpisnice EK ovlaštene su na podnošenje predstavki Sudu na povrede ljudskih prava, kako bi ih Sud u propisanom postupku otklonio. Bitne karakteristike ove državne predstavke su da se radi o «objektivnoj»

12 U slučaju Costello-Roberts protiv Velike Britanije koji se odnosio na slučaj tjelesnog kažnjavanja u pojedinim britanskim privatnim školama o čemu je ESLJP raspravljao. U ovom slučaju ESLJP je utvrdio da država ima obavezu da djeci osigura pravo na obrazovanje, uključujući i odgovornost za sustav discipline u školama, kako privatnim tako i državnim školama, jer je čl. 1. Konvencije određeno da države ugovornice osiguravaju prava i slobode utvrđene Konvencijom svim osobama u svojoj nadležnosti.

13 Vidi Širić, M., Organizaciona struktura i postupak pred Europskim sudom za ljudska prava, Pravna misao, br. 5-6/06, Sarajevo, 2006., str. 100.

14 Sud je u djelomičnoj odluci o dopuštenosti zahtjeva Multiplex i Smailagić protiv Hrvatske, u dijelu gdje je podnositelj Smailagić prigovarao da je bio prisiljen napustiti svoj dom u Banja Luci, Bosna i Hercegovina i pozvao se na čl. 8. EK i čl. 3. st. 1. Protokola broj 4., našao da je taj dio zahtjeva nespojiv ratione personae s EK jer je usmjeren protiv Bosne i Hercegovine, koja tada još nije bila ugovoma stranka EK. 
predstavci koju može podnijeti svaka država i u povodu svakoga kršenja odredbi EK. Ovdje se ne radi, dakle, o tome da države pokreću postupak kada su u pitanju njeni vlastiti interesi ili kršenja ljudskih prava koja se tiču nje same ili njenih državljana, nego se radi o predstavci koja ukazuje na povrede ljudskih prava bez obzira tko ih vrši i protiv koga. Nije, dakle, u pitanju primarni «državni interes» nego je u pitanju interes «europskog javnog poretka».

Druga karakteristika ove državne predstavke je da ona nije zasnovana na principu reciprociteta koji je uobičajen u klasičnim odnosima među državama. Da bi se pokrenuo postupak pred Sudom dovoljno je da postoji prekršaj ljudskih prava koji je počinila neka država koja je članica EK. Zahtjev se može podnijeti radi svake navodne povrede odredaba EK i dodatnih protokola od strane druge države potpisnice. ${ }^{15}$

Predstavke koje podnose države radi zaštite ljudskih prava, baš zbog ovog svog velikog značaja, ne podliježu ocjeni o prihvatljivosti od strane Komiteta, kao što je to slučaj s predstavkama koje podnose pojedinci (EK, čl. 28.). Državne predstavke, kao oznaka kolektivnih jamstava ljudskih prava i njihova objektivnog karaktera, automatski se registriraju i razmatraju pred odgovarajućim vijećem. U tom slučaju vijeće koje je konstituirano u tu svrhu, imenuje dva izvjestitelja iz reda svojih članova i raspravlja o prihvatljivosti određene državne predstavke (poslovnik Suda, čl. 35.). ${ }^{16}$

Razlika između međudržavnih žalbi u odnosu na individualne je u tome što se država protiv države može žaliti na zakonodavne mjere ili neku praksu apstraktno, ne dokazujući njihov štetni efekt po samu državu podnositelja žalbe. Pojedinac, pak, mora dokazivati da ga određena mjera direktno i osobno pogađa, tj. onemogućava u korištenju prava i sloboda iz EK. Druga specifičnost međudržavne žalbe je što se ona dostavlja na odgovor tuženoj strani prije donošenja odluke o prihvatljivosti, dok kod individualnih žalbi to nije slučaj. $U$ dosadašnjoj praksi ta vrsta zahtjeva bila je relativno rijetko korištena.

\subsubsection{Međudržavni sporovi}

Prema čl. 33., koji se odnosi na međudržavne sporove, svaka visoka strana ugovornica može ukazati Sudu na svaku povredu prava utvrđenih i zaštićenih

$15 \mathrm{Na}$ ovaj način vrijednost ovog principa je prvenstveno u novoj prirodi odnosa među državama, koja je označena u prvom redu u mogućnosti miješanja u poslove druge države, onda kada treba zaštititi ljudska prava koja su navedena u EK. Činjenica da se još uvijek pred Sudom nije pojavilo puno ovakvih predstavki, ništa ne umanjuje značaj ovog principa i napretka koji je ostvaren kako u zaštiti ljudskih prava, tako i u odnosu među državama, i u napretku samog međunarodnog prava.

16 Poslovnik Suda propisuje uvjete koje mora imati državna predstavka kao što su ime države na koju se ukazuje prekršitelja određenih ljudskih prava, kao i osnovne činjenice i navedene povrede ljudskih prava. Zatim, osnovne kriterije prihvatljivosti kao što su iscrpljenost drugih raspoloživih sredstava i da nije prošao rok od šest mjeseci, i najzad, smisao i cilj predstavke s gledišta prava. 
Konvencijom ili njenim protokolima za koju smatra da se može pripisati nekoj drugoj visokoj strani ugovornici. ${ }^{17}$

Široko određena formulacija prava države na podnošenje predstavke protiv druge države ugovornice predstavlja bitno odstupanje od načela međunarodnog prava koje se odnosi na međudržavne aktivnosti. Država može podnijeti predstavku ESLJP-u ne samo protiv aktivnosti neke države kada je pravo te države u pitanju, nego se predstavka države protiv druge države ugovornice može podnijeti i kada je kršenje počinjeno protiv osoba koje nisu njeni državljani, ili protiv osoba koje nisu državljani neke od država ugovornica, ili su osobe bez državljanstva, ili čak u odnosu na kršenja Konvencije kada su u pitanju državljani odgovorne države. Države mogu podnijeti predstavke koje se odnose na neusklađenost domaćih zakona ili administrativnih postupaka jedne države s Konvencijom, bez potrebe navođenja konkretne osobe kao prekršitelja.

Slučajeve koji su se pred ESLJP-om pojavljivali povodom međudržavnih predstavki u načelu možemo podijeliti na: 1. slučajeve u kojima je država podnositelj tijesno povezana s individualnim žrtvama u kontekstu kroničnog političkog sukoba između država (slučajevi nestalih osoba, povrede imovinskih prava); 2. zaštita vlastitih građana od nezakonitih postupaka druge države; 3 . generalna zaštita. ${ }^{18}$

Države ne pokreću postupke veoma često. Pokretanje postupka uvjetuju politički i ekonomski razlozi. ${ }^{19}$ Za razliku od pojedinačnog zahtjeva, zahtjev koji jedna država stranka podnosi Europskom sudu protiv druge države stranke: 1. može imati obilježja actio popularis jer se ne traži postojanje neposrednog pravnog interesa države podnositeljice zahtjeva koji bi bio povezan s predmetom spora (ne traži se utvrđenje da je država podnositeljica zahtjeva žrtva povrede Konvencije), 2. može biti usmjeren prema osporavanju nacionalnog zakona ili drugog propisa tužene države in abstracto pod uvjetom da navodna povreda izvire iz samog postojanja tog zakona ili drugog propisa koji uvodi, usmjerava ili dopušta mjere koje su nesuglasne sa zaštićenim konvencijskim pravima i slobodama. Prigovori koji su isticali samo činjenicu da tužena država u svom pravu nije izrijekom zabranila neku povredu još uvijek ne znači da postoji povreda Konvencije jer formalna pravna zabrana neke povrede nije jedina metoda kojom se štite konvencijska prava. ${ }^{20}$ Međutim, ako sam

17 Pravilo 46. Pravilnika Suda određuje sadržaj zahtjeva za pokretanje postupka koje su podnijele države ugovornice (međudržavni zahtjev), i treba sadržavati: a) ime strane ugovornice protiv koje se zahtjev podnosi; b) izjavu o činjenicama; c) kratku izjavu o navodnom kršenju Konvencije i relevantnu argumentaciju koja se odnosi na to; d) izjavu o ispunjenosti uvjeta za dopuštenost zahtjeva; e) predmet zahtjeva za pokretanje postupka uz opće indikacije o zahtjevu za pravičnu satisfakciju za u ime navodno oštećene strane ili strana; f) ime i adresu imenovanog punomoćnika; g) kopije relevantnih dokumenata i odluka, sudskih ili drugih koje se odnose na predmet zahtjeva.

18 Tako Carić, S., Evropski sistem ljudskih prava, Fakultet za ekonomiju i inženjerski menadžment u Novom Sadu, 2011., str. 76.

$19 \mathrm{Na}$ žalost, vlade pokreću pitanja ljudskih prava u drugim zemljama samo ako su odnosi s njima ionako loši ili bar ako u njima ne vide važne saveznike ili nemaju privredne interese.

20 Tako Omejec, J., Konvencija za zaštitu ljudskih prava i temeljnih sloboda u praksi Europskog suda za ljudska prava, Strasbourški acquis, Novi informator, Zagreb, 2013., str. 825. (dalje: Omejec, Konvencija). 
osporeni zakon ili drugi propis nije „sročen jezikom dovoljno jasnim i preciznim da povreda bude odmah vidljiva“, ESLJP mora ispitati „način na koji odgovorna država tumači i primjenjuje in concreto osporeni tekst ili tekstove“. U tom slučaju riječ je o ispitivanju zakonodavne ili upravne prakse u tuženoj državi. ${ }^{21}$

\subsection{Pojedinačni zahtjevi}

Temeljem čl. 34. EK Sud može primati zahtjeve bilo koje fizičke osobe, nevladine organizacije ${ }^{22}$ ili skupine pojedinaca koji tvrde da su žrtve povrede prava priznatih u Konvenciji ili dodatnim protokolima što ih je počinila jedna visoka ugovorna stranka. Visoke ugovorne stranke obvezuju se da ni na koji način neće sprečavati djelotvorno vršenje toga prava. ${ }^{23} \mathrm{Na}$ temelju ove odredbe se kao stranka u sporu može pojaviti i pojedinac. On može podnijeti zahtjev protiv svake države ugovornice Konvencije koja ima nadležnost štititi prava i slobode po čl. 1. Konvencije.

Pravo na pojedinačnu tužbu predstavlja jedno od najučinkovitijih sredstava zaštite ljudskih prava i ujedno je bitni element nadzornog mehanizma koji je utvrđen EK. ${ }^{24}$ Pravilo o nadležnosti Suda ratione personae ima dva posebna aspekta. Zahtjev je neusklađen ratione personae s odredbama EK: kad je podnesen protiv države koja nije stranka EK ili protiv privatne osobe ili kad podnositelj zahtjeva ne dokaže da bi mogao biti žrtvom povrede prava iz EK. Nije relevantno je li podnositelj žalbe državljanin države protiv koje se žali (ili pravna osoba koja pripada toj državi). ${ }^{25}$ Najčešće je riječ o državi čiji je i sam državljanin. Pravo na podnošenje predstavke ograničava se ne samo na državljane države ugovornice nego i na sve osobe koje su bile unutar jurisdikcije država ugovornica gdje se navodno kršenje dogodilo. ${ }^{26}$

Ako predstavku podnosi nevladina organizacija ili grupa pojedinaca, potpisuju je osobe ovlaštene za zastupanje te organizacije ili grupe. ${ }^{27}$ Nadležno vijeće ili

21 Loc. cit.. To se ispitivanje po naravi stvari mora provoditi in concreto, ali ne pretpostavlja odlučivanje ESLJP-a o svakom pojedinačnom slučaju koji čini tu praksu.

22 Nevladine organizacije moraju biti privatne organizacije (novine, crkve, različite asocijacije).

23 Posljednjih godina javlja se pitanje značenja obveze država da "ni na koji način ne sprječavaju učinkovito vršenje" prava na podnošenje pojedinačne tužbe temeljem čl. 34. EK. Sud je zauzeo stav da je bit ove odredbe u osiguranju da podnositelji zahtjeva ili potencijalni podnositelji zahtjeva mogu slobodno komunicirati sa Sudom bez bilo kakvog oblika pritiska vlasti da povuku ili izmjene svoje tužbe.

24 Op. cit. Gomien, D., Kratki vodič kroz Europsku konvenciju o ljudskim pravima, Strasbourg, Vijeće Europe, 1995., str. 271.

25 Vidi Šaula, V., Europski sud za ljudska prava - organizacija, nadležnost i postupak, Pravna misao, godina XXXIII., br. 7-8/02, Sarajevo, 2002., str. 13.

26 Nedostatak poslovne sposobnosti ne utječe na pravo fizičke osobe da podnese predstavku. To se odnosi i na osobe koje su izgubile poslovnu sposobnost poslije smještaja u psihijatrijske ustanove.

27 Grupe koje mogu podnositi predstavke moraju biti propisno registrirane u skladu sa zakonodavstvom jedne od država ugovornica ili predstavka mora biti potpisana od strane svih osoba koje pripadaju toj grupi. 
odbor procjenjuje jesu li osobe potpisnici predstavke na to ovlašteni (pravilo 45. st. 2. Poslovnika Suda). Oni predstavljaju zastupnike drugih, a ne žrtve navodne povrede Konvencije. ${ }^{28}$ Dok države predstavke mogu podnositi in abstracto, pojedinci, nevladine organizacije i grupe osoba moraju tvrditi da su žrtve kršenja prava i sloboda iz Konvencije jedne od strana ugovornica. Pojedinac ne može podnijeti actio popularis niti Sudu može podnijeti apstraktne predstavke. ${ }^{29}$ Podnositelj predstavke mora biti direktna ili indirektna žrtva kršenja prava i sloboda iz Konvencije što ga je počinila država ugovornica koja tuži. Kao indirektne žrtve najčešće se pojavljuju srodnici direktne žrtve (djeca, roditelji, braća i sestre, bračni drug), a pravilo je da se oni pojavljuju pred ESLJP-om ako žrtva nije živa. ${ }^{30}$ Ako u tijeku postupka pred ESLJP-om podnositelj predstavke umre predmet se ne okončava, već ga mogu nastaviti njegovi nasljednici ako dokažu da za to imaju pravni interes. Za prihvatljivost predstavke podnositelj ne mora dokazati da je žrtva kršenja Konvencije nego samo osoba koja tvrdi da je žrtva. Pojedinci, nevladine organizacije i grupe osoba mogu podnositi predstavke sami ili preko svojih zastupnika. ${ }^{31}$ Zahtjev Sudu ne može podnijeti punomoćnik u ime preminule osobe. U predmetu Kolarić-Kišur Vesna protiv Hrvatske ${ }^{32}$ Sud navodi da zahtjev ne može podnijeti punomoćnik u ime preminule osobe, budući da preminula osoba nije sposobna, čak ni putem punomoćnika podnijeti zahtjev Sudu. ${ }^{33} \mathrm{~S}$ obzirom na to da je gospođa Kolarić-Kišur umrla više od pet mjeseci prije nego što je njen punomoćnik podnio zahtjev u njeno ime, proizlazi da predmet nije pokrenula osoba koju se može smatrati podnositeljem zahtjeva u smislu čl. 34. EK. ${ }^{34}$ Stoga je predmetni zahtjev nespojiv ratione personae s odredbama EK u smislu čl. 35. st. 3. te mora biti odbačen temeljem čl. 35 . st. $4 .{ }^{35}$

28 Nevladine organizacije zbog svoje prirode ne mogu koristiti neka od zaštićenih prava (sloboda savjesti, podvrgavanje ponižavajućem postupanju ili kažnjavanju).

29 Vidjeti presudu upredmetu KlassidrugiprotivNjemačke od 6. rujna 1978., SerijaA, br. 28. str. 17.18. st. 33.

30 Sud nalazi da uvjeti koji uređuju pojedinačne zahtjeve na temelju čl. 34. EK nisu nužno isti kao i nacionalni kriteriji koji se odnose na locus standi. Čak i u "skupnim" zahtjevima svaki pojedinac unutar skupine mora tvrditi da je žrtva. Međutim, pravna osoba, poput, primjerice registrirane udruge, može u odgovarajućim okolnostima podnijeti tužbu u ime svojih članova. Kroz sudsku praksu razvio se pojam «potencijalne žrtve», koji omogućuje pojedincima podnošenje individualnih zahtjeva i u slučajevima kada nisu osobno pogođeni određenim postupcima ili odredbama koje se primjenjuju u nekoj od država potpisnica EK. U tim slučajevirna potrebno je učiniti vjerojatnim da samo postojanje takvih odredbi ili postupaka može dovesti do povrede zaštićenih prava u odnosu na konkretnog podnositelja.

31 Zastupnik podnositelja predstavke može biti odvjetnik koji ima pravo obavljati poslove odvjetništva u svakoj državi ugovornici i s boravištem na teritoriju jedne od njih, ali i svaka druga osoba uz odobrenje predsjednika vijeća (pravilo 36. st. 4. Poslovnika Suda).

32 Kolarić- Kišur, Vesna protiv Hrvatske, Odluka o dopuštenosti od 17. rujna 2009., br.: $17129 / 05$.

33 Vidi Yasav.Turkey, br.22495/93,izviješćeKomisijeod8.travnja1997.,st. 88, Izviješćao presudamai odlukama 1998.

34 Vidi Post v. Netherlands (dec.), br. 21727/8, od 20. siječnja 2009.

35 Vidi Dupin v. Croatia (dec.), br. 36868/03, od 7. srpnja 2009. 
Pojam ,žrtva“, u kontekstu ovog članka nedovoljno je precizan. Točno je da se pojam „victim“ koji koristi ESLJP najčešće u našem jeziku prevodi sa „„̌rtva“, ali mišljenja smo da bi termin „oštećeni“ bio mnogo adekvatniji za tumačenje i primjenu, bliži pravom značenju, sadržaju i funkciji odredbe čl. 34. EK, pogotovo što uključuje i sve elemente i oznake koje podrazumijeva pojam „victim“. Status žrtve je preduvjet za prihvaćanja individualne predstavke ESLJP-a. Iako je utvrđivanje takvog statusa pojedinca kao podnositelja predstavke na prvi pogled jasno, brojni slučajevi povreda Konvencije otvaraju dvojbe kada se podnositelj predstavke nesporno može smatrati žrtvom. Sadržaj tog pojma određuje se kroz praksu ESLJP-a. Međutim, može doći do određene pojmovne odnosno suštinske zabune u odnosu na razgraničenje pojmova direktne i indirektne žrtve, u slučaju kada se ESLJP-u podnosi predstavka u ime preminulog, kao i u odnosu na gubitak statusa žrtve. Osnovni uvjet za podnošenje predstavke ESLJP-u je da podnositelj „tvrdi da je žrtva“. Postavlja se pitanje što će se desiti ako je žrtva mrtva. To bi značilo da sa smrću osobe kojoj je povrijeđeno neko pravo iz Konvencije nestaje mogućnost iznošenja te povrede pred ESLJP-om. S obzirom da bi to bilo nepravično uvoden je pojam indirektne žrtve.

Sadržaj pojma direktne žrtve utvrdio je ESLJP odlučujući u predmetu Eckle protiv Njemačke. ${ }^{36}$ Iz navedene odluke proizlazi da, kada je neka osoba direktno pogođena nekim štetnim događajem ili propuštanjem, nije potreban dodatni uvjet da bi se smatrala žrtvom. I nema dvojbe u odnosu na "direktno“ oštećenog pojedinca, a u smislu vidljivog postojanja posljedice koja je u jasnom i očiglednom odnosu s uzrokom. Međutim i u slučaju da je neka osoba posredno pogođena (,indirectly affected") ne može joj se osporiti da je žrtva i potrebno je utvrditi je li indirektna žrtva.

Sud priznaje pravo za podnošenje zahtjeva za pokretanje postupka i bliskim članovima obitelji i supružniku same žrtve, iako ove osobe nisu bile direktne žrtve, već je na njih indirektno utjecala povreda prava utvrđenih Konvencijom ili njenim protokolima, zbog bliskog odnosa sa žrtvom. Smatramo da bi u okviru pojma „indirektna žrtva“ bilo potrebno uvesti dodatne kriterije kako bi se oni slučajevi kada „posredno pogođenoj osobi“ treba omogućiti ostvarenje zaštite pred ESLJPom, razgraničili od slučaja kada neka osoba pokušava putem predstavke pred ESLJP-om istaknuti zahtjev koji je zapravo actio popularis. ${ }^{37} \mathrm{U}$ praksi se otvara i pitanje koje se tiče stava o dopuštenosti podnošenja predstavki u ime preminulih osoba. U teoriji su prisutni stavovi po kojima je nedopušteno, odnosno izričito zabranjeno podnošenje predstavki u ime preminulih. ${ }^{38}$ Međutim, ako pogledamo

36 Eckle v Federal Republic of Germany (series a, no 51, application no 8130/78) European court of human rights (1983) 5 ehrr 1, 15 july 1982.

37 Kako bi ESLJP uvažio predstavku podnositelja koji je indirektna žrtva moraju se ESLJP-u pružiti nesporni i uvjerljivi dokazi o postojanju neposredne i direktne veze između opisane povrede određenog prava zaštićenog Konvencijom i događaja koji je tu povredu prouzrokovao. Opširnije Novaković, M., Pojam indirektne žrtve u jurisprudenciji Evropskog suda za ljudska prava, Strani pravni život, br. 1., 2011., str. 261-269.

38 Lič, F., Obraćanje Evropskom sudu za ljudska prava, Knjiga 1, Beograd, 2007, str. 120. 
praksu ESLJP-a u nekim predmetima se daje izričiti i obrazložni odgovor na pitanje kada će ESLJP dozvoliti, odnosno odbaciti zahtjev podnesen u ime preminulog. To su predmeti Kurt protiv Turske ${ }^{39}$ i Sanles Sanles protiv Španjolske. ${ }^{40}$ U predmetu Kurt protiv Turske, podnositelj predstavke bila je majka turskog vojnika, koji je nestao u operacijama turske vojske. Ona je dugo vremena pred turskim organima bezuspješno pokušavala saznati što se dogodilo s njenim sinom. Kada se obratila ESLJP-u, to je učinila predstavkom podnijetom i u svoje ime (zbog povrede čl. 3. i 13. Konvencije), ali i u ime sina (zbog povrede čl. 2., 5., 14. i 17. Konvencije).

U predmetu Sanles Sanles protiv Španjolske podnošenju predstavke je prethodila okolnost da je teško oboljeli gospodin Sampedro u Španjolskoj vodio dugogodišnju pravnu bitku kako bi mu se omogućilo da umre „dobrovoljno i bezbolno“, a da izvršitelji tog „čina“ ne budu kažnjeni. Poslije neuspješne borbe da mu se odobri eutanazija, gospodin Sampedro okončava život na način na koji je i želio, a „pomagači“ nisu otkriveni. Njegova šogorica, gospođa Sanles, koju je ovlastio da nastavi pravnu borbu poslije njegove smrti podnijela je predstavku ESLJP-u u ime svog pokojnog zeta, zahtijevajući u ime svog vlastodavca da se na osnovu čl. 2., 3., 5., 6., 8., 9. i 14. Konvencije prizna pravo na dostojanstvenu smrt.

U prvom slučaju ESLJP je dopustio pokretanje postupka u ime preminule osobe, $\mathrm{tj}$. sina podnositelja predstavke (gospođe Kurt), a u drugom slučaju ESLJP nije dopustio da se pokrene postupak u ime zeta gospođe Sanles, iako su u oba slučaja podnositelji predstavke bili ovlašteni pravni sljednici pokojnika. Ovdje vidimo dva kriterija: institut legitimnog interesa s jedne i okolnost da direktna žrtva nije u stanju podnijeti predstavku (preminula), s druge strane. Predstavka kojom je pokrenut postupak u predmetu Kurt protiv Turske ispunjava oba kriterija, jer je gospođa Kurt nesporno dokazala legitimni interes da podnese zahtjev u ime svog sina, s obzirom na to da on kao direktna žrtva, nije u stanju to učiniti sam. S druge strane, u slučaju Sanles Sanles protiv Španjolske, suci su zauzeli stav da nije zastupljen dovoljan legitiman interes, $\mathrm{tj}$. da gospođa Sanles podnijetom predstavkom djeluje putem actio popularis. Odbor za ljudska prava, pred kojim se ovaj slučaj našao ${ }^{41}$ nije našao da se u odnosu na gospodina Sampedra može govoriti o statusu žrtve. Dakle, njegova smrt je nastupila 1998. godine, a šogorica je na osnovi ovlaštenja tek 2001. godine pokušala pred ESLJP-om „nastaviti“ borbu za pravo da se povodom „samoubojstva uz pomoć ostalih“ kazneno ne gone supočinitelji, za gospodina Ramona se nije moglo osnovano tvrditi da je bio žrtva povrede prava koja štiti Konvencija.

Ako bi se propisom ili praksom ESLJP-a onemogućilo pokretanje postupka pred ESLJP-om u ime umrlog došlo bi do apsurdne situacije koja je suprotna osnovnom cilju u kojem je ESLJP i ustanovljen. Ovdje se postavlja pitanje kako zaštititi pravo umrloga ako sama žrtva ne može pokrenuti postupak, a da se

39 Kurt v. Turkey, app. No. 24276/94.

40 Sanles Sanles v. Spain, app. No. 48335/99

41 http:/www.humanrights.is/thehumanrightsrpoject/humanrightscasesandmaterials/cases/ internationalcases/humanrightscommittee/nr/335 
ne ostavi prostor za predstavke koje će nastojati tu mogućnost zloupotrijebiti. Problem je što se u praksi ESLJP-a osoba koja pokreće postupak u ime umrloga smatra indirektnom žrtvom. Međutim, indirektna žrtva je ona koja je pogođena nekim propuštanjem koje nije usmjereno izravno na nju, ali ona trpi štetu. Osoba koja pokreće postupak u ime umrlog njegovom smrću nije postala indirektna žrtva kada pokreće postupak $u$ ime umrlog, jer taj postupak pokreće zbog nemogućnosti umrlog da sam to učini. Dakle, osoba koja bi dokazala da je smrću njoj bliske osobe došlo do povrede njenog prava iz Konvencije i dokazala uzročno posljedičnu vezu bila bi indirektna žrtva. Ali, i tada bi ta osoba tražila zaštitu svog prava u svoje ime i ukazivala bi na činjenicu iz koje je proizlazila povreda njenog prava, ali u svoje ime. Međutim, podnošenje predstavke $u$ ime preminule osobe ne predstavlja takvu situaciju. ${ }^{42}$

Iz prakse ESLJP-a proizilazi da će se gotovo uvijek dopustiti pokretanje ili nastavak postupka poslije smrti podnositelja predstavke, kada nasljednici kao sukcesori podnose predstavku ili stupaju u već pokrenuti postupak. Međutim, ima i slučajeva kada ESLJP to nije odobravao. U slučaju Kurt protiv Turske bila je riječ o predstavci u kojoj je majka poginulog vojnika, pored pozivanja na povredu prava iz čl. 3. i 13. Konvencije (u svoje ime), ukazivala i na povredu prava iz čl. 2., 5., 14. i 17. Konvencije (u ime svog sina). Za Sud je bilo nesporno postojanje povrede zabrane mučenja, nečovječnog i ponižavajućeg postupanja iz čl. 3. Konvencije. Međutim, stav ESLJP-a u odnosu na povredu prava zaštićenih tim člankom i nije bio predmet osporavanja, jer je u odnosu na takva postupanja gospođa Kurt i bila direktna žrtva. Naime, ona se žalila na tretman koji je ona doživjela od policije i sudstva prilikom nastojanja da sazna šta se desilo njenom sinu. Međutim, ESLJP je usvojio i onaj dio predstavke u kojem je majka ukazivala na povredu prava njenog sina iz čl. 5. i 13. Konvencije. ${ }^{43}$ Ovdje se ESLJP potvrdio da činjenica da neka osoba podnosi predstavku u ime umrloga nema nikakve veze sa tim je li ona sama žrtva. ${ }^{44}$

Smatramo da bi aktivnu legitimaciju, odnosno priznati pravo na pokretanje postupak pred ESLJP-om u ime umrloga trebalo priznati podnositelju predstavke koji, pored ukazivanja na postojanje činjenice da direktna žrtva nije u stanju sama podnijeti predstavku, dokaže i pravni interes za obraćanje ESLJP-u u tuđe ime. Interes se dokazuje okolnostima bliske rodbinske veze ili činjenicom da je neka osoba nasljednik umrloga. Istovremeno, što se tiče statusa indirektne žrtve, ne osporava se ni mogućnost stjecanja tog „svojstva“ u osobi istog podnositelja uz

42 Razlog tome možemo naći u potrebi ESLJP-a da omogući zaštitu prava na život (čl. 2. Konvencije) a da ne prekrši čl. 34 Konvencije u kojem se inzistira da podnesak može podnijeti samo žrtva (ne navodi izričito je li riječ o direktnoj ili indirektnoj). Još jedan primjer za tzv. indirektne žrtve je predmet Chahal protiv Velike Britanije. Sudu se obratio gospodin Chahal kao direktna žrtva, ali su se Sudu obratili i njegova supruga i djeca pozivajući se na čl. 8 Konvencije, odnosno tvrdeći da im je povrijeđeno pravo na obiteljski život. Chahal protiv Velike Britanije 15.11.1996., para.68.

43 I to jednoglasno, za razliku od zahtjeva pozivom na povredu čl. 3. koje je usvojio sa 19 glasova za dok i ih je 5 bilo protiv.

44 Tako Novaković, M., op.cit. (bilj. 37.), str. 261-269. 
uvjet da ta osoba dokaže takvo svojstvo iz okolnosti da je zaista pogođena nekom povredom Konvencije koja nije učinjena njoj osobno, ali i da dokaže da joj je s tim posredno povrijeđeno pravo zajamčeno Konvencijom. Nije moguće taksativno nabrojati sve slučajeve u kojima je neka osoba žrtva u smislu odredaba Konvencije. Trebalo bi težiti postavljanju jedne opće definicije koja bi formulirala okvirni pojam žrtve. To bi bio značajan putokaz potencijalnim podnositeljima predstavki, a istovremeno i doprinos učinkovitosti i ujednačavanju prakse ESLJP -a. Jedan slučaj iz prakse ESLJP-a je dao poseban doprinos tom nužnom preciziranju odnosno sužavanju pojma žrtve. U predmetu Eckle protiv Njemačke ${ }^{45}$ ESLJP se nije bavio situacijama i pitanjima kada netko dobiva status žrtve, već onima kada se taj status gubi, što je za utvrđivanje postojanja i trajanje statusa žrtve podjednako važno. ${ }^{46}$ Prema stajalištu ESLJP-a izraženom u tom predmetu, status žrtve u smislu Konvencije gubi se uslijed: priznanja statusa žrtve podnositelju predstavke; davanja obeštećenja podnositelju predstavke ${ }^{47}$; konkludentnim radnjama uzetog u obzir kršenja prava podnositelja predstavke kao žrtve. Navedenim radnjama osoba ne prestaje biti žrtva uopće već prestaje biti žrtva za ESLJP. ${ }^{48}$

Jedan od osnovnih principa na kojima počiva ESLJP je da će se njegova „uloga“ odnosno „status“ žrtve pred ESLJP-om aktivirati tek ako, i pored iscrpljenih svih domaćih pravnih lijekova, žrtva nije dobila nikakvu ili adekvatnu zaštitu od države. ${ }^{49}$

U odnosu na zahtjev da je podnositelj žrtva prava zajamčenih EK ne traži se da podnositelj zahtjeva dokaže da je povreda zaista i nastupila. To je pitanje osnovanosti samog zahtjeva o kojem se odlučuje u presudi. Dovoljno je da iz okolnosti predmeta proizlazi da se radi o situaciji koja bi, ako su navodi podnositelja koji se odnose na činjenično stanje točni, mogla predstavljati povredu njegovih

45 Eckle v. Germany, app. No. 8130/78

46 Do gubitka statusa žrtve došlo je i u slučaju Caraher protiv Velike Britanije (Caraher protiv Velike Britanije 11.01.2000.) u kome je britansko Ministarstvo obrane u tijeku postupka pred ESLJP-om u vezi sa ubojstvom supruga podnositelja zahtjeva u Sjevernoj Irskoj isplatilo 50.000 britanskih funti podnositelju zahtjeva, zbog čega je ESLJP ustanovio da zahtjev nije dopušten, jer podnositelj zahtjeva više nije imao status žrtve po Konvenciji.

47 U određenim slučajevima da bi podnositelj zahtjeva izgubio status žrtve sama kompenzacija nije dovoljna, ako je ponašanje državnih vlasti kojim je povrijeđeno pravo zajamčeno Konvencijom ili njenim protokolima, suglasno zakonskim odredbama te države.

48 Primjenom navedenih kriterija stav ESLJP-a u slučaju Moustaquim protiv Belgije (Moustaquim protiv Belgije 19.02.1991. para. 31), koji se odnosio na deportaciju, iako je država ugovornica dopustila podnositelju zahtjeva da ostane u Belgiji, nedavanje naknade za petogodišnji strah koji je podnositelj zahtjeva pretrpio zbog patnje da će biti deportiran, ESLJP je tretirao kao povredu Konvencije i odbio tvrdnju Belgije da je svrha zahtjeva ostvarena time što mu je dopušten ostanak u državi.

49 Ali, ako „,national authorities have acknowledged either expressly or in substance, and then afforded redress for, the breach of the Convention" (Eckle v. Germany, app. No. 8130/78, paragraph 66.), potreba za intervencijom ESLJP-a prestaje. ESLJP je u mnogim kasnijim slučajevima, potvrdio ovakav stav (Dalban v. Romania, app. No. 28114/95; Chevrol v. France, app. No. 49636/99.). 
prava zajamčenih EK. ${ }^{50}$ Sud smatra da čl. 34. EK pojedincima omogućuje tvrditi kako neki zakon njihova prava krši sam po sebi, i onda kad nema pojedinačnih mjera provedbe, ako su oni izloženi riziku da njime budu izravno pogođeni. ${ }^{51}$

\section{NADLEŽNOST SUDA RATIONE MATERIAE}

Države mogu podnijeti predstavku o svakom navodnom kršenju odredaba EK koje je počinila druga visoka ugovornica, a ne samo onih odredaba iz odjeljka 1. EK dok pojedinci mogu uspješno podnijeti predstavku samo po pravima određenim EK, što znači da se njihove pritužbe mogu odnositi samo na članke iz odjeljka 1. EK i članke Protokola koji sadrže dodatna prava. Dio 1. EK sadrži sljedeća prava i slobode: pravo na život, sloboda od mučenja, neljudskog ili ponižavajućeg postupka, sloboda od ropstva i prinudnog ili obveznog rada, pravo na slobodu i sigurnost ličnosti, pravo na pravično i javno suđenje u razumnom roku, sloboda od retroaktivne primjene kaznenog zakonodavstva, pravo na poštivanje privatnog i obiteljskog života, doma i prepiske, sloboda misli, savjesti i vjeroispovijesti, sloboda izražavanja, sloboda okupljanja i udruživanja i pravo na sklapanje braka

50 Primjerice u predmetu Mladenić protiv Hrvatske Vlada je prigovarala da zahtjev nije sukladan ratione persone s odredbama EK, jer je postupak pred Ustavnim sudom obustavljen zbog propusta podnositelja zahtjeva da obavijesti Ustavni sud o svojoj novoj adresi, da stoga podnositeIj zahtjeva nije žrtva nikakve povrede prava zajamčenih EK, jer je do obustave postupka na koji prigovara došlo njegovom krivnjom. Sud, je međutim, našao da je zahtjev podnesen protiv države koja je ratificirala EK i protiv odluke Ustavnog suda da obustavi postupak u povodu ustavne tužbe podnositelja zahtjeva. Nadalje, podnositelj zahtjeva može tvrditi da je žrtva povrede prava zajamčenih EK, jer navodi da je činjenica da je postupak pred Ustavnim sudom obustavljen bez donošenja odluke o osnovanosti njegove tužbe i da je povrijeđeno njegovo pravo na pristup sudu, a što će Sud ispitati na temelju čl. 6. st. 1. EK. Sud je zahtjev proglasio nedopuštenim, ali iz drugih razloga. Vidi Perić, M., Uvjeti dopuštenosti pokretanja postupka pred Europskim sudom za ljudska prava u Strasbourgu, magistarski znanstveni rad, Mostar, 2010., str. 160-161. (dalje: Perić, Uvjeti dopuštenosti).

51 Vidjeti presudu u predmetu Johnston i drugi protiv Irske od 18. prosinca 1986., Serija A, br. 112, str. 21., st. 42. i presudu u predmetu Marckx protiv Belgije od 13. lipnja 1979., Serija A., br. 31, str. 13., st. 27. U ovom predmetu zakon koji je predmet prigovora nije nikad primijenjen na podnositelja zahtjeva - njegov je zahtjev u naravi bio actio popularis kojim je on tražio in abstracto preispitivanje osporenog zakona u svjetlu EK ... Cak i predmnijevajući da potencijalni korisnici prava koja proizlaze iz osporavanog zakona imaju pravo na zaštitu koju jamči čl. 1. Protokola broj 1., Sud primjećuje da je podnositelj zahtjeva propustio dokazati da bi on sam na bilo koj i način mogao biti pogođen osporavanim zakonom. Njegov je glavni prigovor taj da se tim zakonom krši pravo na vlasništvo kao takvo. Sud primjećuje da nema dovoljno izravne povezanosti između podnositelja zahtjeva kao takvog i povrede za koju tvrdi da ju je pretrpio zbog navodnog kršenja EK. U vezi s time, Sud podsjeća da osoba koja nije u mogućnosti dokazati da je osobno pogođena primjenom zakona kojeg kritizira ne može tvrditi da je žrtva kršenja EK (vidjeti br. 9939/82 Odluka od 4. 7.1983., Zbirka odluka i izviješća br. 34., str. 213.). Iz tih razloga, podnositelj zahtjeva se ne može smatrati žrtvom povrede prava utvrđenih EK». 
i zasnivanje obitelji. ${ }^{52}$ Osobitu pažnju valja obratiti na čl. 6. EK, koji jamči pravo na pošteno suđenje u postupcima u kojima se odlučuje o podnositeljevim pravima i obvezama građanske prirode ili ako imaju obilježja kaznenog postupka. ${ }^{53}$ Čl. 6 . EK ne odnosi se na postupke u kojima se odlučuje samo o troškovima nekog postupka, kao o glavnoj stvari te na postupke koji se odnose na procesna pitanja (npr. postupak u kojem je tužba ili žalba odbačena radi procesnih nedostataka, kao što je nedostatak valjane punomoći za zastupanje ili nepravovremenost podneska, nadalje ne odnosi se na postupak u povodu zahtjeva za ponavljanjem parničnog postupka ali ako se ponavljanje odobri, čl. 6. EK se primjenjuje na taj novi postupak, jer je to jedan redoviti parnični postupak, te se odnosi niti na porezne postupke)..$^{54} 55$

\section{NADLEŽNOST SUDA RATIONE TEMPORIS}

Nadležnost Suda obuhvaća sve akte i propuste države ugovornice učinjene poslije stupanja na snagu Konvencije. Tako da odredbe Konvencije ne obvezuju ugovornu stranku u odnosu na bilo koji akt ili činjenicu koji su se dogodili ili na bilo koju situaciju koja je prestala postojati prije datuma stupanja na snagu Konvencije, činjenica koje datiraju iz razdoblja kad tužena država nije bila u položaju predvidjeti

52 Protokol 1. dodaje sljedeća prava: pravo na mirno uživanje imovine, pravo na obrazovanje i slobodan izbor obrazovanja i pravo na slobodne izbore tajnim glasovanjem. Protokol 4. uključuje sljedeća prava i slobode: zabrana lišavanja slobode po osnovu nemogućnosti ispunjenja ugovornih obveza, sloboda kretanja i sloboda izbora boravišta unutar zemlje, zabrana protjerivanja državljana i pravo državljana da uđu na teritorij države čiji su državljani i zabrana skupnog protjerivanja stranaca. Protokolom 6. uz EK od 28. travnja 1983. smrtna kazna je ukinuta. Ipak, ostavljena je mogućnost da država zadrži smrtnu kaznu za vrijeme rata ili neposredne ratne opasnosti. Konačno, Protokolom 13. uz EK od 3. svibnja 2002. smrtna kazna je ukinuta u svim okolnostima. Protokol 7. sadrži sljedeća prava i slobode: proceduralna jamstva u slučaju protjerivanja stranaca koji zakonito borave na teritorijujedne države, pravo na preispitivanje kaznenih predmeta pred višim sudom, pravo na naknadu osobi osuđenoj za kazneno djelo, ako neka nova ili novootkrivena činjenica pokaže da se radilo o sudskoj pogrešci, zabrana novog kaznenog postupka za djelo za koje je osoba već pravomoćno oslobođena ili osuđena i jednakost supružnika u pravima i obvezama."

53 Više Grdinić, E., Pravo na pošteno suđenje u postupcima građanskopravne prirode zajamčeno čl 6. st.1. Europske konvencije za zaštitu ljudskih prava i temeljnih sloboda, rujan, 2005., str. $7-16$.

54 Sud je donio 19. travnja 2007. godine presudu kojom je izmijenio svoju dosadašnju praksu u pogledu primjene čl. 6. st. 1. EK (prava na pravično sudenje) na sporove koje državni službenici pokreću protiv svog poslodavca. Od tada, da bi se isključila zaštita iz čl. 6. EK moraju biti ispunjena dva uvjeta. Kao prvo, država mora u svom domaćern pravu izričito isključiti pristup sudu za to radno mjesto ili kategoriju zaposlenika. Kao drugo, isključenje mora biti opravdano objektivnim razlozima državnog interesa. Sama činjenica da podnositelj radi u sektoru koji sudjeluje u izvršavanju ovlasti dodijeljenih javnim pravom nije sama po sebi odlučna. Prema tome, u pravilu ne može biti opravdanja za isključenje jamstava iz čl. 6 . EK za obične radne sporove, kao što su oni koji se odnose na plaće, dodatke i slična prava."

55 Čl. 6. EK se ne odnosi na: postupke u povodu stjecanja državljanstva, ekstradicijske postupke ili postupke u kojima se odlučuje o boravku stranog državljanina u nekoj zemlji. 
međunarodnu odgovornost ili pravni postupak kome su ove činjenice mogle biti uzrokom u odnosu na tu stranku. Taj datum ovisi o državi protiv koje se podnosi zahtjev, ovisno o tome odnosi li se zahtjev na pravo navedeno u samoj Konvenciji ili u jednom od protokola. Sud je zauzeo stajalište da je Konvencija prema pojedinim članicama mjerodavna samo za događaje koji su se dogodili nakon što je ona za njih stupila na snagu (vidi Multiplex ${ }^{56}$ i Kastelić v. $R H^{57}$ ). Sud nije nadležan ispitati zahtjeve za pokretanje postupka protiv države ako su navodne povrede zasnovane na činjenicama koje su se dogodile prije odlučnog datuma, osim ako učinjena povreda nema trajni karakter. ${ }^{58}$ Kada su događaji na koje se odnosi zahtjev dogodili prije stupanja Konvencije na snagu u odnosu na predmetnu državu, a nastavljeni su i nakon tog datuma, Sud će uzeti kao relevantne samo događaje nakon stupanja na snagu Konvencije. ${ }^{59}$

U predmetu Stamoulakatos v. Greece ${ }^{60}$ podnositelj zahtjeva je prigovorio protiv sudskih presuda donesenih protiv njega in absentia od strane grčkih sudova prije datuma kojeg je Grčka prihvatila pravo na pojedinačne zahtjeve na temelju bivšeg čl. 25. Konvencije. ${ }^{61}$ Međutim, podnositelj je žalbe protiv tih sudskih presuda,

56 Multiplex protiv Hrvatske (Odluka od 26.9.2002., zahtjev br. 58112/00). Sud u ovom predmetu nalazi da je, premda je zakonodavno miješanje nastupilo nakon što je Konvencija stupila na snagu u odnosu na Hrvatsku, ono bilo u toj mjeri povezano sa događajima koji su dali povod zahtjevu podnositeljice da bi njihovo razdvajanje vodilo davanju retroaktivnog učinka Konvenciji koje bi bilo suprotno općim načelima međunarodnog prava. U isto vrijeme to bi učinilo Hrvatsku izjavu kojom se priznaje nadležnost Suda za zaprimanje pojedinačnih zahtjeva ništavom (vidi Stamulakatos protiv Grčke, presuda od 30. rujna 1993., Serija A br. 271 , str. $14, \S 33)$.

57 Kastelić protiv Hrvatske (Odluka od 07.11.2002., zahtjev br. 60533/00). Sud podsjeća da je Hrvatska priznala nadležnost Suda da prima zahtjeve od "bilo koje fizičke osobe, nevladine organizacije ili skupine pojedinaca koji tvrde da su žrtve povrede prava priznatih u ovoj Konvenciji počinjene od Hrvatske bilo kojim aktom, odlukom ili događajem nastalim nakon 5. studenog 1997." U skladu s navedenim, Sud nije nadležan ispitati ovaj zahtjev u onom dijelu u kojem on upućuje na činjenice koje su nastale prije dana ratifikacije Konvencije.

58 Bečka Konvencija o pravu međunarodnih ugovora iz 1969., čl. 28. predviđa da ugovori nemaju retroaktivno djelovanje.

59 Pri procjeni razumnog trajanja dužine postupka pred domaćim organima, Sud će uzeti u obzir samo vrijeme nakon stupanja Konvencije na snagu, ali će imati i na umu i koliko je postupak trajao i prije stupanja na snagu Konvencije, kao i okolnosti koje su utjecale na njegovu dužinu kao u slučaju Vajagić protiv Hrvatske. Vajagić protiv Hrvatske 16.10.2008.

60 Stamoulakatos v. Greece, 26. 10. 1993. para. 32-33.

61 U presudi Stamoulakatos protiv Grčke u odnosu na tri presude koje su grčki sudovi donijeli prije ratifikacije EK, Sud je jasno našao da je svaki zahtjev koji bi se odnosio na povredu konvencijskih prava u tim postupcima izvan vremenske nadležnosti Suda. U odnosu, pak na žalbene postupke protiv tih presuda, koji su se odvijali nakon ratifikacije EK od strane Grčke Sud je naveo: «U pogledu žalbenih postupaka protiv tih presuda, podnositelj se žali isključivo u smislu da mu nije putem tih žalbenih postupaka bilo i omogućeno novo ispitivanje merituma njegovog predmeta pred sudom prvog stupnja, a s obzirom da mu se sudilo u odsutnosti. Stoga, iako je podnositelj pokrenuo žalbene postupke nakon «kritičnog» datuma, 19. studenoga 1985. (datum kada je Grčka ratificirala EK), ti postupci usko su vezani s postupkom koji je doveo do osude podnositelja ... Rastavljati žalbene postupke od događaja koji su ih uzrokovali bi, u okolnostima ovog predmeta, bilo jednako negiranju grčke Deklaracije o ratifikacij i EK. 
koje su bile nakon toga odbijene, uložio nakon tog datuma. ESLJP je presudio da su te žalbe, iako su bile podnesene nakon mjerodavnog datuma, povezane s postupkom koji je doveo do njegovih presuda. ${ }^{62}$ Sud je smatrao da bi rastavljanje odluka domaćih sudova donesenih nakon ratifikacije, od događaja koji su doveli do sudskog postupka bilo ravno poništenju izjave Grčke kojim prihvaća pravo pojedinačnih zahtjeva i da bi značilo davanje retroaktivnog djelovanja Konvenciji, što bi bilo protiv općih načela međunarodnoga prava. Sud je ovaj zahtjev proglasio nespojivim s Konvencijom ratione temporis. ${ }^{63}$

Kada Sud razmatra razumni rok, stajališta je da on nikako ne može početi teći prije stupanja na snagu EK s obzirom na tuženu državu. Sukladno navedenom, zahtjevi koji se odnose na događaje koji su nastupili prije datuma ratifikacije EK od strane pojedine države nisu u nadležnosti Suda. Takvo stajalište Sud je izrazio u nizu svojih odluka. Kod ispitivanja vremenske nadležnosti Suda treba razlikovati dvije situacije. Prva je ona u kojoj navodna povreda prava zajamčenih EK predstavlja trenutni akt, kao što su primjerice, otkaz s posla ili čin uništenja nečije imovine. Ako se taj akt dogodio prije ratifikacije EK Sud, neće biti nadležan iako su se možebitne odluke domaćih sudova koje se odnose na tu situaciju donijele nakon ratifikacije. ${ }^{64}$ Druga situacija je ona koja predstavlja kontinuirano kršenje prava zajamčenih EK. Najčešći primjer takve situacije su zahtjevi koji se odnose na povredu prava na suđenje u razumnom roku. Naime, i postupci koji su započeli prije ratifikacije EK, ako je njihovo trajanje nastavljeno nakon ratifikacije, ulazit će u vremensku nadležnost Suda. Pritom će Sud detaljno razmotriti tijek postupka nakon ratifikacije, ali će ipak uzeti u obzir ukupnu duljinu trajanja postupka, kao i stanje predmeta nakon ratifikacije. U situacijama koje su se dogodile prije stupanja na snagu u odnosu na predmetnu državu Sud će obratiti posebnu pažnju na to je li

62 U predmetu Zana v. Turkey (Zana v. Turkey 25. 11. 1997. para. 42.) podnositelj zahtjeva je prigovorio da mu je povrijeđeno pravo utvrđeno čl. 10. Konvencije, jer je domaći sud donio sudsku presudu protiv njega 26. ožujka 1991. godine zbog izjave koju je dao novinarima u kolovozu 1987. godine. Turska je prihvatila obveznu nadležnost Suda samo u odnosu na činjenice i događaje koji su se dogodili poslije 22. siječnja 1990. godine, odnosno nakon dana kada je dostavila svoju izjavu. Sud nije prihvatio tvrdnju turske vlade da je mjerodavna glavna činjenica za uspostavu nadležnosti ratione temporis bila izjava podnositelja zahtjeva novinarima. Naprotiv, glavna je činjenica bila sudska presuda protiv podnositelja zahtjeva, time što je ta presuda predstavljala povredu prava podnositelja zahtjeva na osnovu čl. 10. Sud je prema tome odbacio prethodni prigovor Vlade na temelju nenadležnosti ratione temporis.

63 Blečić protiv Hrvatske, 08.03.2006. para. 92.

64 U predmetu Juravić protiv Hrvatske podnositelj zahtjeva bio je zaposlen u poduzeću E. od 19. srpnja 1994. godine do 4. veljače 1995. godine kad je dobio otkaz. Kako bi osporio svoj otkaz, pokrenuo je dva postupka: upravni postupak i građanski postupak. «Glede poštenosti upravnog postupka, Sud primjećuje da je on okončan 1995. godine, dok je EK stupila na snagu u odnosu na Hrvatsku 5. studenog 1997. godine. Glede poštenosti građanskog postupka, Sud primjećuje da je postupak još u tijeku i da je taj prigovor stoga preuranjen. Slijedi da su ovi prigovori: (a) nesuklađeni ratione temporis s odredbama EK u smislu čl. 35. st. 3. i (b) nedopušteni na temelju čl. 35. st. 1. zbog neiscrpljivanja domaćih pravnih sredstava, tim redom». 
riječ o događaju koji ima trajni karakter. ${ }^{65}$

Zahtjev mora biti podnesen unutar razdoblja od šest mjeseci od dana donošenja konačne odluke najvišeg nadležnog domaćeg suda ili organa. Razdoblje od šest mjeseci računa se od datuma kada je konačna odluka u redovitom sudskom postupku dostavljena stranci ili odvjetniku, a ne od datuma eventualnog kasnijeg odbijanja zahtjeva za ponavljanjem postupka ili bilo kojeg drugog zahtjeva nekom od organa koji nema utjecaja na ishod spora. ${ }^{66}$ Razdoblje od šest mjeseci prekida se $\mathrm{u}$ trenutku kada ESLJP primi prvi dopis u kojem je jasno iznesen predmet zahtjeva koji se želi podnijeti ili ispunjeni obrazac zahtjeva. ${ }^{67}$

Svrha je pravila o šest mjeseci promicati pravnu sigurnost i osigurati da se s predmetima, u kojima postoje sporna pitanja vezano uz Konvenciju, postupa u razumnom roku te da se zaštiti vlast $i$ druge osobe kojih se to tiče od svake neizvjesnosti kroz produljeno vremensko razdoblje. ${ }^{68}$

Datum od kojeg vremensko ograničenje počinje teći ne odnosi se samo na datum na koji je odluka domaćih sudova donesena, nego i na vrijeme od kojeg je podnositelj zahtjeva bio obaviješten o rezultatu postupka i stoga bio u rnogućnosti podnijeti tužbu Sudu. U praksi se računa od dana kad je podnositelj, odnosno njegov odvjetnik primio tu odluku. Ako je datum dostave znatno kasniji od dana donošenja odluke potrebno je o tome priložiti dokaz. Da bi počelo teći razdoblje od šest mjeseci, naknadna obavijest $\mathbf{O}$ punom tekstu u kojoj se daju razlozi presude može biti odlučujuća. Ako je odluka donesena za vrijeme javne rasprave na kojoj je podnositelju bilo dopušteno sudjelovati, kao datum konačne odluke domaćih sudova smatra se datum rasprave. Ako pak odluka nije donesena na raspravi, meritoran je datum proglašenja presude. Stupanjem na snagu Pakta o građanskim i političkim pravima i Fakultativnog protokola uz taj Pakt, pružena je mogućnost zaštite prava onim pojedincima kojima je prošao ovaj rok za podnošenje tužbe Sudu.

65 U slučaju trenutnih događaja van vremenskih okvira EK, predstavka će uvijek biti proglašena neprihvatljivorn ratione temporis. U predmetu Pilipović protiv Hrvatske Sud ponav1ja da se odgovomost države za ovrhu pravomoćnih presuda protiv privatnih osoba ne proteže dalje od sudjelovanja državnih tijela u ovršnorn postupku. Nakon što je ovršni postupak završen u skladu s nacionalnirn zakonodavstvom, odgovomost države prestaje. U ovom predmetu Sud smatra utvrđenim da je ovršni postupak o kojemu se radi okončan 04. veljače 1993. godine, dakle prije stupanja na snagu EK u odnosu na Hrvatsku 5. studenog 1997. godine. Uzimajući naprijed navedeno u obzir, Sud smatra da neuspješni pokušaji podnositelja zahtjeva da nakon 1999. godine nastavi ovršni postupak koji je već bio okončan - mogućnost koja ne postoji prema mjerodavnom domaćem zakonodavstvu - ne rnogu taj postupak dovesti u vremensku nadležnost Suda.

66 Vezano uz datum podnošenja zahtjeva Sudu, Sud je već utvrdio da se datum poštanskog pečata kojim se evidentira dan kad je zahtjev upućen smatra datumom podnošenja zahtjeva, a ne datum primitka označen pečatom na zahtjevu (vidi, na primjer, Kipritçi protiv Turske, br. 14294/04, stavak 18., 3. lipnja 2008.)

67 Ako se dopisom samo zatraže informacije od ESLJP-a, time se ne prekida rok od šest mjeseci koji je potrebno poštovati.

68 Vidi Kelly protiv Ujedinjenog Kraljevstva, br. 10626/83, Odluka Komisije od 7. svibnja 1985., Odluke i izvješća (DR) 42, str. 205 i Baybora i drugi protiv Cipra (odl.), br. 77116/01, 22. listopada 2002. 
Fakultativni protokol daje pojedincima pravo podnošenja pritužbe Odboru za prava čovjeka u Genevi, zbog kršenja tog Pakta od neke države stranke. Pritom će Odbor razmatrati samo priopćenja osoba koje su iscrpile sva raspoloživa unutamja pravna sredstva, i to pod uvjetom da taj isti predmet nije već podvrgnut nekom drugom međunarodnorn postupku. Dakle, ne traži se vremensko ograničenje kao jedan od uvjeta dopuštenosti tužbe.

U predmetima u kojima ne postoji pravo žalbe na odluku ili akt javne vlasti, rok počinje teći od trenutka kada odluka ili akt postanu pravomoćni. Kada se zahtjev odnosi na primjenu pravnog propisa koji za posljedicu ima trajnu povredu prava, ne postoji nikakav mogući «početak» za računanje roka. U slučaju da postoje izuzeci od iscrpljivanja pravnih lijekova (npr. nedjelotvomost ili nedostupnost pravnog lijeka) predstavka se podnosi u roku od šest mjeseci od trenutka kada se navodno kršenje prava dogodilo. Ako je riječ o više nepovezanih događaja za koje podnositelj ukazuje da predstavljaju kršenje, najsigurnije za njega je uzeti u obzir prvi događaj. Međutim, ako su događaji međusobno povezani tako da čine jedan jedinstveni događaj, za primjenu pravila od šest mjeseci relevantan je posljednji događaj u nizu. Rok od šest mjeseci ne vrijedi za kontinuirane situacije kršenja prava zajamčenih EK- tipičan primjer je zahtjev radi suđenja u razumnom roku zahtjev se može podnijeti sve dok postupak traje pa i kad završi, ali tada, unutar roka od šest mjeseci od završetka postupka. ${ }^{69}$

Vremensko ograničenje od šest mjeseci neće se primijeniti ako je riječ o povredi koja ima trajni karakter. ${ }^{70}$ Drugi slučaj kada se pravilo od šest mjeseci neće primijeniti odnosi se na korištenje nedjelotvornog pravnog sredstva. U tom slučaju rok od šest mjeseci teći će od trenutka kada je uporabljeno djelotvorno pravno sredstvo, tj. od trenutka samog događaja ako nije bilo djelotvornog pravnog sredstva. Ako postoji bilo kakva sumnja o djelotvrnosti nekog pravnog sredstva za podnositelje predstavke bilo bi važno da Sudu u roku od šest mjeseci od posljednje pravomoćne odluke domaćih tijela podnesu jedno uvodno pismo. Ako je podnositelj zahtjeva koristio pravne lijekove koji nisu bili dopušteni, onda se njihovo korištenje ne može smatrati prekidom tijeka roka od šest mjeseci predviđenog. Za pitanje je li

69 Nemoguće je unaprijed okvalificirati pojedino razdoblje kao razumno odnosno nerazumno, ali je dosadašnja praksa Suda odredila kada taj rok počinje teći i kada završava. U građanskim postupcima vrijeme počinje teći kada je stvar iznesena pred nadležni sud, ali nikada ne može početi teći prije stupanja na snagu EK s obzirom na tuženu državu. Sud mora voditi računa o tome do kojeg stupnja se postupak razvio u tom prethodnom razdoblju. U građanskorn kao i u kaznenom postupku vremensko razdoblje prestaje teći kad zadnja sudska odluka koja je donesena u domaćem pravnom poretku postane res iudicata, bez obzira na razinu u sudskoj piramidi na kojoj je odluka donesena.

70 U praksi Suda bilo je više situacija koje je Sud kvalificirao kao trajne povrede. To se odnosilo na razdoblje provedeno u pritvoru, postojanje izvjesnih zakona kojima se krši EK, odbijanje plaćanja naknade zbog eksproprijacije ili nacionalizacije, koje same po sebi predstavljaju trenutne akte, odbijanje vlade da podnositelju pruži informacije u vezi s testiranjem kemijskog oružja nad njim dok je bio vojnik šezdesetih godina, kontinuirano ograničavanje slobode izražavanja kao posljedica osude za izdaju tijekom Drugog svjetskog rata, neprovođenje odluke o načinu održavanja kontakta s djetetom itd. 
predstavka podnesena pravovremeno - relevantni datum je onaj kada je potvrđeno da je predstavka stigla u «Glavno tajništvo». U praksi, Komisija kao odlučujući trenutak uzima datum prvog pisma podnositelja u kojem on izražava želju za podnošenjem zahtjeva i daje neku naznaku naravi svoje pritužbe. ${ }^{71}$

\section{UVJETI DOPUŠTENOSTI IZ ČL. 35. KONVENCIJE}

Konvencijom je propisano da Sud može razmatrati predmet samo nakon što su iscrpljena sva raspoloživa domaća pravna sredstva, u skladu s općeprihvaćenim pravilima međunarodnog prava i unutar razdoblja od šest mjeseci od dana donošenja konačne odluke te Sud neće razmatrati niti jedan pojedinačni zahtjev podnesen na temelju čl. 34. EK koji je: anoniman ili u osnovi isti kao neki predmet što ga je sud već ispitivao, ili koji je već podvrgnut nekom drugom međunarodnom postupku istrage ili rješavanja te ako ne sadrži nikakve nove relevantne činjenice.

\section{1. Iscrpljivanje domaćih pravnih lijekova}

Podnositelj zahtjeva mora iskoristi sve unutarnje pravne lijekove koji su mu na raspolaganju, redovne i izvanredne, administrativne ili sudske. ${ }^{72}$ Tužitelj mora

71 Kao primjer podnošenja zahtjeva izvan roka od šest mjeseei nalazimo u predmetu Modrić protiv Hrvatske gdje se navodi da je podnositeljica zahtjeva išla baciti smeće kad joj je iznenada pristupio njen susjed, određeni B.L., ošamario je i navodno je počeo daviti zaprijetivši joj da će je ubiti. Uspjela je pobjeći i prijaviti ga policiji. Policija je Prekršajnom sudu u Splitu podnijela prijavu protiv B.L.-a te je pred tim sudom pokrenut postupak protiv B.L ... «U ovom predmetu Sud primjećuje da je 14. prosinca 2004. godine vijeće Županijskoga suda u Splitu sastavljeno od tri suca odbilo zahtjev za provođenje istrage koji je podnositeljica zahtjeva podnijela istražnome sucu Županijskoga suda u Splitu. Podnositeljica zahtjeva je nakon toga podnijela nekoliko daljnjih žalbi koje su sve odbačene, jer nisu propisane Zakonom o kaznenom postupku. Ustavni sud je 24. studenog 2005. donio odluku o nedopuštenosti u odnosu na te žalbe. Zahtjev Sudu je podnesen 26. travnja 2006. godine, dakle manje od šest mjeseci od dana donošenja odluke Ustavnoga suda, ali više od šest mjeseci nakon dana donošenja odluke Županijskoga suda u Splitu, kojom je odbijen zahtjev podnositeljice za provođenjem istrage. Podnositeljica zahtjeva je mogla pokušati podnijeti ustavnu tužbu protiv odluke Županijskoga suda u Splitu od 14. prosinca 2004. godine, kojom je odbijen njen zahtjev za provođenjem istrage. Suprotno tome, ustavna tužba podnesena u odnosu na postupovne odluke kojima se žalbe podnositeljice zahtjeva odbacuju jer nisu propisane mjerodavnim pravom, nije pravno sredstvo koje treba iscrpiti u smislu čl. 35. st. 1. EK. Stoga pravna sredstva koja je pokušala iskoristiti podnositeljica zahtjeva nakon odluke Županijskoga suda u Splitu od 14. prosinca 2004. godine ne mogu prekinuti tijek roka od šest mjeseci iz čl. 35. st. 1. EK. Sud tako dolazi do zaključka da je rok od šest mjeseci započeo teći najkasnije 14. prosinca 2004. godine, kad je vijeće Županijskoga suda u Splitu odbilo zahtjev podnositeljice zahtjeva za provođenjem istrage. Zahtjev je podnesen 26. travnja 2006. godine, više od šest mjeseci nakon toga. Slijedi da je zahtjev podnesen prekasno, te ga treba odbiti u skladu s čl. 35. st. 1. EK».

72 Tako prigovor podnesen Sudu treba prvo biti podnesen odgovarajućim nacionalnim sudovima, u skladu s formalnim zahtjevima domaćega prava i u propisanim rokovima. Drugačije 
dokazati ESLJP-u da je htio da se slučaj riješi, iznoseći sve argumente u prilog povoljnog rješenja slučaja pred domaćim tijelima, a ne da je njegov postupak ulaganja žalbe bio samo da bi se zadovoljio formalni zahtjev korištenja unutarnjih pravnih lijekova. Domaćim nadležnim organima uvijek treba dati mogućnost da „isprave“ povredu prava zaštićenih Konvencijom, ${ }^{73}$ prije nego ga ESLJP uzme u razmatranje. ${ }^{74}$ Ovo pravilo pretpostavlja postojanje određenih uvjeta koji su neophodni za njegovu primjenu: a) postojanje i dostupnost pravnih lijekova; b) djelotvornost pravnih lijekova i da su dovoljni u ostvarivanju zaštite prava te c) postojanje općih uvjeta za normalnu realizaciju unutarnjih pravnih lijekova. ${ }^{75}$

Ipak, obveza iscrpiti domaća pravna sredstva zahtijeva samo da podnositelj na uobičajen način upotrijebi pravna sredstva koja su djelotvorna, dostatna i na raspolaganju u odnosu na njegove pritužbe na temelju Konvencije. ${ }^{76}$ Postojanje pravnih sredstava mora biti dostatno izvjesno, u praksi kao i u teoriji, jer će im u suprotnom nedostajati potrebna dostupnost i učinkovitost. ${ }^{77}$ Pravna sredstva koja su dostupna stranci na domaćoj razini smatraju se učinkovitima ako sprječavaju navodnu povredu ili njezino nastavljanje, ili ako pružaju primjerenu zadovoljštinu za bilo koju povredu do koje je već došlo. ${ }^{78} \mathrm{U}$ suprotnom podnositelj zahtjeva mora dokazati da bi takva sredstva bila nedjelotvorna. ${ }^{79}$

stajalište značilo bi udvostručivanje domaćega procesa i postupka pred Sudom, što bi se teško moglo smatrati spojivim sa supsidijarnim značajem Konvencije. Vidi predmet Gavril Yosifov protiv Bugarske, br. 74012/01, stavak 42., 6. studeni 2008.

73 Vidi, primjerice, predmet Hentrich protiv Francuske, 22. rujna 1994., st. 33., serija A, br. 296-A te predmet Remli protiv Francuske, 23. travnja 1996., st. 33., Izvješća 1996.-II.

74 Ovo se pravilo temelji na predmnjevi koja je izražena u čl. 13. Konvencije, a s kojim je blisko povezana, kako je u domaćem sustavu na raspolaganju učinkovito sredstvo u odnosu na navodnu povredu, bez obzira na to jesu li odredbe Konvencije preuzete u nacionalnom pravu ili ne. To je važan vid načela prema kojem je mehanizam zaštite uspostavljen Konvencijom supsidijaran nacionalnim sustavima kojima se štite ljudska prava. Vidi presudu Handyside v. United Kingdom, od 7. prosinca 1976., Serija A, br. 24, str. 22, st. 48. i presudu Aksoy v. Turkey od 18. prosinca 1996., Reports of Judgments, Judgments and Decisions 1996-VI, str. 2275, 2276, st. 51.

75 Međutim, ima situacija u kojima se iscrpljivanje unutarnjih pravnih lijekova neće postavljati kao neophodan uvjet za prihvatljivost zahtjeva za pokretanje postupka. To su slučajevi vezani za povredu čl. 6. st. 1. Konvencije, odnosno povredu prava na suđenje u razumnom roku, kao i slučajeve vezane za čl. 33. Konvencije, koji se odnosi na međudržavne sporove. Djelotvornost pravnih lijekova se naročito procjenjuje kada riječ o slučajevima dugotrajnih postupaka pred domaćim organima i ako ESLJP utvrdi da se radi o povredi prava na suđenje u razumnom roku, podnositelj zahtjeva će biti oslobođen obveze iscrpljivanja unutarnjih pravnih lijekova. Više Krapac, D., Postupak pred Ustavnim sudom Republike Hrvatske, Ustrojstvo i proceduralni elementi ustavnog nadzor, Narodne novine, 2014., str. 60 - 66.

76 Vidi predmete Balogh protiv Madžarske, br. 47940/99, stavak 30., 20. srpnja 2004. i John Sammut i Visa Investments Limited protiv Malte (odluka), br. 27023/03, 28. lipnja 2005.).

77 Vidi predmet Aksoy protiv Turske, 18. prosinca 1996., stavci 51. - 52., Izvješća o presudama i odlukama 1996-VI te predmet Barta protiv Mađarske, br. 26137/04, stavak 45., 10. travnja 2007.

78 Vidi predmet Mifsud protiv Francuske (odl.) [VV], br. 57220/00, stavak 17., ESLJP 2002VIII.

79 Vidi, među ostalim izvorima, Akdivar i drugi protiv Turske, 16. rujna 1996., stavci 65. i 68., Izvješća o presudama i odlukama 1996-IV. 
Pravilo o iscrpljivanju domaćih pravnih sredstava nije apsolutno, niti se može primijeniti automatski. Pri ispitivanju je li bilo poštovano, bitno je uzeti u obzir određene okolnosti svakoga pojedinog predmeta. ${ }^{80}$ To znači da se mora uzeti u obzir postojanje formalnih pravnih sredstava u pravnom sustavu ugovorne stranke i sveukupni pravni i politički kontekst unutar kojeg one djeluju te osobne prilike podnositelja zahtjeva. ${ }^{81}$

Kada je riječ o dostupnosti pravnog lijeka, da bi bio dostupan potrebno je da podnositelj zahtjeva ima pravo direktnog obraćanja domaćem nadležnom organu, administrativnom ili sudskom. ESLJP navodi da se u primjenu ovoga pravila mora uzeti u obzir kontekst. ${ }^{82}$ Za ESLJP nije dovoljno da država tvrdi da je osigurala postojanje pravnih lijekova, već može zahtijevati od države iznošenje primjera slučajeva u kojima je pravo na pravni lijek uspješno iskorišteno. ${ }^{83}$

Teret dokazivanja da nisu iscrpljeni svi unutarnji lijekovi uvijek je na državi protiv koje je podnesen zahtjev za pokretanje postupka, odnosno na Vladi koja se poziva na neiscrpljivanje unutarnjih pravnih lijekova i koja je dužna uvjeriti ESLJP da je pravni lijek bio djelotvoran i na raspolaganju podnositelju zahtjeva, da je mogao pružiti pravnu zaštitu u odnosu na prigovore podnositelja zahtjeva te da je davao razumne izglede za uspjeh. Međutim, kada se razrješi pitanje tereta dokaza, na podnositelju zahtjeva je da dokaže da je pravno sredstvo na koje se poziva Vlada bilo iscrpljeno ili je iz nekoga razloga bilo nedostatno i nedjelotvorno ili su postojale posebne okolnosti zbog kojih je on bio oslobođen tog uvjeta.

ESLJP će smatrati da pravni lijek nije dostupan ako zavisi o diskrecijskoj ocjeni samog suda ${ }^{84} \mathrm{U}$ slučaju Horvat protiv Hrvatske ${ }^{85}$ ESLJP nije prihvatio argumente hrvatske Vlade da nisu iscrpljeni svi unutarnji pravni lijekovi predviđeni

80 Vidi presudu Van Oosterwijck v. Belgium od 6. studenog 1980., Serija A, br. 40, str. 18, st. 35.; presudu Cardot v. France od 19. ožujka 1991., Serija A br. 200, str. 18, st. 34. U predmetu Immobliare Saffi protiv Italije ESLJP je zaključio da obraćanje Ustavnom sudu u Italiji nije pravno sredstvo koje je podnositelj zahtjeva trebao iscrpiti, zbog toga što se pravo direktnog obraćanja sudu nije odnosilo na Ustavni sud.

81 Vidi presudu Akdivar and Others v. Turkey od 16. rujna 1996., Reports of Judgements and Decisions 1996-IV, str. 1210-1211, st. 65-68.

82 Dostupnost pravnog lijeka ESLJP ocjenjuje i na osnovu okolnosti samog slučaja, ako je nemogućnost korištenja pravnog lijeka prouzrokovana slabim materijalnim stanjem osoba, ako mu nije priznato pravo na besplatnu pravnu pomoć u slučajevima u kojima nije obavezna obrana ili u složenijim slučajevima, i na osnovu ovih okolnosti ESLJP može pravni lijek proglasiti nedostupnim.

83 ESLJP je utvrdio da pravni lijekovi nisu bili dostupni, uzimajući u obzir okolnosti, u predmetu Conka protiv Belgije gdje je ESLJP uzeo da su podnositelji zahtjeva obaviješteni o mogućnosti upotrebe pravnog lijeka tek u policijskoj stanici, na jeziku koji nisu razumjeli, jer je samo jedan prevoditelj bio na raspolaganju velikom broju romskih obitelji, kao i da su nadležne vlasti propustile da ih blagovremeno upoznaju sa pravom na branitelja. Zbog ovih okolnosti nije bilo potrebno ispunjavanje uvjeta iscrpljivanja svih unutrašnjih pravnih lijekova.

84 Vidi presudu Vernillo v. France od 20. veljače 1991., Serija A, br. 198, str. 11-12, st. 27., i Dalia v. France, br. 26102/95, st. 38., ECHR 1998-I.

85 Horvat protiv Hrvatske, presuda od 26.07.2001., zahtjev br. 51585/99. 
pravom RH zato što se podnositelj zahtjeva nije obratio Ustavnom sudu RH, jer je ESLJP istaknuo da pravni lijek ne predstavlja dostupno pravno sredstvo ako zavisi o diskrecijskoj ocjeni samog suda. ${ }^{86}{ }^{87} \mathrm{U}$ određenim slučajevima ESLJP je zauzeo stav da, ako postoji više mogućih unutarnjih pravnih lijekova, podnositelj zahtjeva ih nije obavezan sve iscrpiti ili čak iskoristiti više od jednog, ako sa istim ne bi postigao nešto više i ako u državi postoji ukorijenjeno pravno mišljenje o tome da nema izglede za uspjeh.

Zahtjev da su prethodno iscrpljeni svi raspoloživi domaći pravni lijekovi proizlazi iz načela supsidijarnosti EK kao međunarodnopravnog instrumenta. Nacionalna prava određuju koja pravna sredstva trebaju biti iscrpljena. Tamo gdje ih postoji nekoliko, podnositelj zahtjeva mora razumnim argumentima objasniti zašto se odlučio za određeni pravni lijek. Podnositelj zahtjeva je dužan iscrpiti samo one pravne lijekove koji su mu dostupni kao pravo, a ne kao privilegij. Ako su neki pravni lijek odbacila domaća tijela iz procesnih razloga kao što su nepravovremenost, neurednost podneska, nedopuštenost itd., tada domaći pravni lijekovi nisu uredno iscrpljeni. Država mora imati priliku prije svega sama ispraviti situaciju povrede konvencijskih prava, a da bi to mogla, pretpostavka je da je njezinim tijelima upućen zahtjev za popravkom kršenja ljudskih prava. ${ }^{88}$

Pravilo iscrpljivanja domaćih pravnih lijekova ne vrijedi za međudržavne pritužbe koje se odnose na zakonodavne mjere ili administrativnu praksu druge države, a da pritužba nije povezana za jednu ili više osoba koje su žrtve takve zakonodavne ili administrativne prakse. U tim slučajevima nema pojedinaca koji moraju iscrpiti domaće pravne lijekove, dok se od same države ne može očekivati da pokrene postupak pred vlastima odgovorne države. Iscrpljivanje unutarnjih pravnih lijekova se neće postavljati kao neophodan uvjet ni u slučaju povrede čl. 6. st. 1. EK, tj. povrede prava na suđenje u razumnom roku. Pravni lijek mora biti efikasan i adekvatan.

Podnositelj zahtjeva pred domaćim sudovima ne mora se pozvati na EK kada se poziva na domaće pravne propise čiji je sadržaj u bitnom sličan. Međutim, mora se pozvati na EK kada ona predstavlja jedinu pravnu osnovu za njegov tužbeni zahtjev pred domaćim sudom. Lijek se ne mora tražiti ako postoji jasno ustanovljena sudska praksa koja pokazuje da ne nudi realnu šansu za uspjeh. Međutim, u tom slučaju podnositelj mora dati neki dokaz da takva sudska praksa postoji. Pravni lijek

86 U ovom predmetu ESLJP primjećuje kako se smatra da je postupak na temelju članka 59. stavka 4. Ustavnog zakona o Ustavnom sudu pokrenut samo ako Ustavni sud, nakon prethodnog ispitivanja tužbe, odluči da je dopusti. Tako, iako osoba o kojoj se radi može podnijeti ustavnu tužbu izravno Ustavnom sudu, formalno pokretanje takvog postupka ovisi o diskrecijskoj ocjeni tog suda.

87 Također, u slučaju Öclan protiv Turske po ocjeni ESLJP-a zbog specifičnih okolnosti podnositelj zahtjeva je bio oslobođen obaveze da iscrpi unutrašnje pravne lijekove, time što je bio onemogucen jer je neprestano držan u potpunoj izolaciji od strane državnih vlasti i nije imao prilike da se konzultira sa svojim braniteljem, a sam nije imao pravno obrazovanje.

88 Vidi Perić, M., Uvjeti dopuštenosti podnošenja zahtjeva građana Bosne i Hercegovine Europskom sudu za ljudska prava u Strasbourgu, Pravna misao, br. 7-8, 2011., str. 61-64. 
nije u potpunosti djelotvoran ako nadležni sud nije u potpunosti nezavisan. Komisija je prihvatila rnogućnost da, u skladu s općeprihvaćenim pravilima međunarodnog prava, mogu postojati posebne okolnosti u kojima efikasni i adekvatni lijekovi mogu ostati neiskorišteni. To su: sumnja podnositelja u djelotvornost relevantnog lijeka, njegovo nepoznavanje (postojanja) određenog lijeka, neprihvaćanje žalbe jer je podnositelj napravio procesnu pogrešku, loše zdravstveno stanje podnositelja, starost podnositelja, loša financijska situacija podnositelja ili visoki troškovi postupka, nedostatak besplatne pravne pomoći, strah od posljedica, pogreške ili pogrešan savjet pravnog zastupnika ili vlasti, dva podnositelja podnose istu pritužbu dok je samo jedan iscrpio domaće pravne lijekove ${ }^{89}$ Djelotvornost pravnih sredstava posebno se procjenjuje u slučajevima predugog trajanja postupka pred domaćim tijelima.

Što se tiče Republike Hrvatske, većina prava i sloboda zajamčenih EK zajamčena je i Ustavom RH. Stoga će u pravilu, prije podnošenja zahtjeva Sudu, biti potrebno obratiti se Ustavnom sudu RH. Pritom je potrebno u ustavnoj tužbi istaknuti iste navode na koje će se podnositelj kasnije pozivati pred Sudom. Međutim, nije potrebno pozivanje na odredbe EK u postupcima pred domaćirn sudovima, već je dovoljno da su povrede u suštini jednake.

\subsection{Anoniman i sadrăajno isti zahtjev}

Sud neće razmatrati niti jedan pojedinačni zahtjev podnesen na temelju čl. 34. koji je: anoniman; ${ }^{90}$ ili u osnovi isti kao neki predmet što ga je Sud već ispitivao; ili koji smatra inkompatibilnim s odredbama Konvencije i dodatnih protokola, očito neosnovanim ili zloupotrebom prava na podnošenje zahtjeva. Zahtjev može biti i „neanoniman“. Riječ je o nepotpisanim zahtjevima (unsigned application) ${ }^{91} \mathrm{i}$ zahtjevima podnesenim pod izmišljenim imenima (fictitious names) ${ }^{92}$.

89 Za sada se u sudskoj praksi posebne okolnosti koje opravdavaju ne iscrpljivanje potvrđuju sarno izuzetno. Važno je napomenuti da odbacivanje zahtjeva zbog toga što domaća pravna sredstva nisu iscrpljena predstavlja samo privremenu prepreku. Sud može ponovno razmotriti isti zahtjev kada ga podnositelj podnese nakon što iscrpi raspoloživa domaća pravna sredstva. Vidi Perić, M., Uvjeti dopuštenosti, str. 172.

90 U predmetu gdje su se dvije organizacije liječnika i medicinskih sestara žalile na neopravdano i diskriminirajuće ometanje prava njihovih članova, liječnika i sestara, na poštovanje privatnih života, Komisija je primijetila da oni sami nisu žrtve kršenja EK. Kada su izjavili da oni predstavljaju različite pojedince, koji su time postali podnositelji, postalo je neophodno da asocijacija identiticira te pojedince i da pokaže da je od svakog od njih primila konkretne upute. Budući da to nije učinjeno, ostatak zahtjeva morao je biti odbijen kao anoniman.

91 Nepotpisan zahtjev jest onaj koji sadržava sve osobne podatke podnositelja dostatne da se eliminira svaka sumnja o njegovu identitetu, a iza kojeg slijedi uredna korespondencija podnositeljeva pravnog savjetnika, vlastoručno potpisana. Takav zahtjev ESLJP ne smatra anonimnim. Na toj je osnovi ESLJP odbacio prethodnu primjedbu ruske vlade o nedopuštenoj anonimnosti zahtjeva u predmetu Kuznetsova protiv Rusije (2006.).

92 Zahtjev podnesen pod izmišljenim imenima jest onaj u kojemu se pojedinci koriste pseudonimima, najčešće obrazlažući ESLJP-u da ih kontekst oružanog sukoba koji traje u 
Svaki zahtjev za pokretanje postupka podnesen ESLJP mora sadržavati određene osobne podatke o podnositelju zahtjeva i podatke koji su potrebni za njegovu identifikaciju. Zahtjev za pokretanje postupka koji ne ispunjava ovaj uvjet će biti proglašen nedopuštenim. ${ }^{93} \mathrm{U}$ zahtjevu koji podnosi Sudu, podnositelj mora navesti svoje ime i prezime kao i druge osobne podatke te zahtjev mora, na kraju, vlastoručno potpisati. Sve odluke Suda su javne te se objavljuju pod imenom i prezimenom podnositelja. Znači podnositelj zahtjeva mora otkriti svoj identitet, tj. zahtjev ne smije biti anoniman. Zahtjev koji ne zadovoljava ovaj uvjet bit će proglašen nedopuštenim. ${ }^{94}$

Pravilo sadržano u pretpostavci, da Sud neće razmatrati isti zahtjev ponovno, sadržano je u načelu ne bis in idem. Tako, Sud neće razmatrati zahtjev koji je već prije razmotren pred tim sudom, ali ni zahtjeve koje je razmotrilo neko drugo međunarodno tijelo. Iznimka od tog pravila su zahtjevi koji sadržavaju nove relevantne činjenice. Nove činjenice moraju biti od takvog značenja da bi mogle utjecati na odluku Suda o tome je li došlo do povrede EK. Mora se raditi o činjenicama koje podnositelju nisu bile poznate u vrijeme kad je Sud prvi put odlučivao o njegovu zahtjevu. Zahtjev treba biti podnesen u roku šest mjeseci od saznanja za nove činjenice ili od posljednje nove domaće odluke. Pojam «novih relevantnih činjenica» odnosi se samo na činjenice koje nisu bile poznate u trenutku podnošenja prethodnog zahtjeva ili su nastale nakon što je Sud već donio odluku. ${ }^{95}$

Zahtjev koji je suštinski isti sa zahtjevom koji je Sud već razmatrao i koji ne sadrži neke nove činjenice relevantne za predmetni slučaj Sud će proglasiti nedopuštenim. To će se svakako odnositi na zahtjev koji je podnio isti podnositelj i koji se tiče istog predmeta o kome je Sud već odlučivao. Međutim, ako je u istoj stvari došlo do promjene podnositelja ili ako isti podnositelji podnesu zahtjev koji je zasnovan na drugim činjenicama od ranijeg zahtjeva, suštinski nije riječ o istom zahtjevu. ${ }^{96}$ Može se zaključiti da riječi «suštinski isto pitanje» uključuju i predstavku koja je identična, ali ju je podnio drugi podnositelj. Ovakva odredba ne

njihovoj zemlji odnsono na području tužene države na kojem oni žive, prisiljava da ne otkriju svoja prava imena jer samo tako mogu zaštititi članove svojih obitelji i prijatelje. U odluci Shamayev i drugi protiv Gruzije i Rusije (2003.), a poslije i u presudi Shamayev i drugi protiv Gruzije i Rusije (2005.), ESLJP nije ih ocijenio nedopuštenima zbog anonimnosti. Tako Omejec, J., Konvencija, str. 573 - 574.

93 Identitet podnositelja zahtjeva se po pravilu ne krije, ali u opravdanim slučajevima predsjednik sudskog vijeća može odobriti mjere za zaštitu identiteta podnositelja zahtjeva ako ga on prethodno zatraži navodeći razloge za anonimnost. Ako Sud odobri ovakav zahtjev podnositelja, podnositelj zahtjeva se može služiti svojim inicijalima. (Poslovnik Suda, pravilo 47. st. 3.).

94 Ovaj uvjet omogućava zabranu predstavki koje su podnesene iz čisto političkih ili propagandnih razloga, iako se mogu zamisliti predmeti u kojima jedan pojedinačni podnositelj želi ostati anoniman iz straha od posljedica.

95 Riječ je o novim činjenicama i u slučaju da za danu državu ugovornicu iz EK proizlaze nove obveze.

96 Međutirn, promjena pravne argumentacije u zahtjevu, pri istom činjeničnom stanju, dovest će do toga da zahtjev bude proglašen neprihvatljivim. 
može se tumačiti u smislu da je usmjerena samo protiv identičnih zahtjeva istog podnositelja. ${ }^{97}$

U slučaju da je Sud prethodno ustanovio da zahtjev nije dopušten jer nisu bila iscrpljena sva pravna sredstva predviđena unutarnjim pravom, nakon iscrpljivanja pravnih sredstava domaćeg prava na koja je ukazao Sud, ako bi podnositelj ponovo podnio zahtjev Sudu, on ne bi bio proglašen nedopuštenim zbog njegove suštinske istovjetnosti sa zahtjevom koji je ranije podnesen Sudu. Ovaj je uvjet obuhvaćen općim načelorn sudskog postupka, koje sprječava litispedencija. To znači da onaj koji podnosi zahtjev Sudu, ne smije to učiniti i prema nekom drugom tijelu za zaštitu ljudskih prava. ${ }^{98}$ Ovakav temelj za neprihvatljivost ne odnosi se na državne zahtjeve.

\subsection{Očito neosnovan zahtjev}

Unajvećem broju odluka o dopuštenosti Sud proglašavazahtjevenedopuštenima, jer utvrđuje da su neosnovani. ${ }^{99}$ Uvjet prihvatljivosti važi samo za pojedinačne predstavke. Naime, malo je vjerojatno da međudržavne predstavke, koje se podnose tek nakon detaljnih diskusija i koje pripremaju stručni pravni savjetnici vlade, mogu biti očigledno neutemeljene. Komisija ne isključuje primjenu općeg pravila koje omogućava proglašavanje predstavke neprihvatljivom. Tako će zahtjev biti očito neosnovan ako su navodi o povredama EK nedovoljno objašnjeni. To znači da se već na prvi pogled vidi da nema temelja za tvrdnju da je EK prekršena. Tim se uvjetom dopuštenosti omogućava Sudu da ne mora ulaziti u meritum zahtjeva kad on, temeljem prethodnog razmatranja, ne upućuje na povredu EK. Zahtjev će se u ranoj fazi razmatranja predmeta proglasiti očito neosnovanim samo kad je temeljem ispitivanja zahtjeva nemoguće uočiti povredu EK. ${ }^{100}$

97 Ne bi bilo u skladu sa svrhom EK da pojedincu da pravnu zaštitu, ako predstavka osobe X, koja smatra da je žrtva kršenja EK, ne bi bila prihvaćena na osnovu činjenice da identično kršenje vezano za osobu Y ispituje, ili je već ispitano. Kako se vidi iz njene sudske prakse, Komisija nije imala ništa protiv identičnih predstavki različitih podnositelja, iako je onda, ako je to moguće, takve predmete spajala. Ako je predstavka i u činjenicama i zakonski (skoro) identična predmetu koji je već bio pred Komisijom, naravno da nije moguće takav predmet spojiti s nekim ranijim, ali se takav zahtjev rješavao po skraćenom postupku.

98 Pitanja vezana uz uvjet da nisu podnesena nekim drugim međunarodni tijelima nisu bila od velike važnosti kada se EK počela tek primjenjivati, ali su postal značajna zbog osnivanja drugih međunarodnih tijela koja se bave ljudskim pravima (Pakt Ujedinjenih naroda o građanskim i političkirn pravima i njegov Fakultativni protokol). Sud neće postupati po pojedinačnom zahtjevu podnijetom na temelju čl. 34. EK ako je on već podnijet nekoj drugoj međunarodnoj instanci radi ispitivanja, odnosno rješavanja, a ne sadrži nove relevantne činjenice (EK, čl. 35., st. 2b).

99 Vidi Grdinić, E., Pretpostavke dopuštenosti zahtjeva podnesenih Europskom sudu za ljudska prava u Strasbourgu, Informator, br. 5300 - 5303, Zagreb, 22, 25. i 29. prosinca 2004. i 1. siječnja 2005., str. 7.

100 Tako Gomien, D., Kratki vodič kroz Europsku konvenciju o ljudskim pravima, Strasbourg, Vijeće Europe, 1995., str. 276. 
U praksi se predstavke proglašavaju očigledno neosnovanim ako činjenice u odnosu na koje se podnosi pritužba, očito ne predstavljaju kršenje EK, ili ako se te činjenice nisu dokazale ili su očigledno netočne. Što se tiče ovog drugog, traži se od podnositelja davanje prima facie dokaza o činjenicama koje predočava. Nije uvijek moguće jasno razlučiti između očigledne neosnovanosti i nekompatibilnosti s EK. Postoji nekompatibilnost ratione materiae, ako se predstavka odnosi na kršenje prava koje nije zaštićeno EK. U tom slučaju, predstavka je u potpunosti izvan opsega EK i nije moguće ispitivanje merituma. Predstavka je očito neosnovana i ako se odnosi na pravo koje je zaštićeno EK, ali se ispitivanjem predočenih činjenica utvrdi da ni na koji način ne mogu opravdati tvrdnju o postojanju kršenja, tako da je ispitivanje merituma nepotrebno. ${ }^{101}$

Predstavka je očito neosnovana kada njen sadržaj ne upućuje na postojanje bilo kakvog oblika prava od strane tužene države na koji se podnositelj predstavke poziva. Postavlja se pitanje odnosa čl. 35. st. 1. EK, kao procesne pretpostavke dopuštenosti zahtjeva za pokretanje postupka i čl. 13. EK. O dopuštenosti Sud odlučuje svojom odlukom. Ako nađe da je zahtjev dopušten, o njegovoj osnovanosti odlučuje presudom. Međutim, ako je pitanje zahtjeva tijesno vezano s pitanjem osnovanosti zahtjeva, Sud može spojiti odlučivanje o oba pitanja i o oba odlučiti presudom. ${ }^{102}$ Tako Sud u slučaju individualnih zahtjeva spaja odlučivanje o dopuštenosti zahtjeva i osnovanosti zahtjeva. U praksi Suda veliki broj predstavki je okončan na ovaj način, tako da prethodno ispitivanje dopuštenosti predstavke predstavlja jednu vrstu filtra za sve predstavke koje nisu dovoljno utemeljene. Za takvu odluku potrebna je jednoglasnost članova odbora koji je odlučivao o dopuštenosti predstavke, ali predstavka može biti po ovoj osnovi proglašena nedopuštena u kasnijoj fazi, kada je o njoj obaviještena vlada države respodenta. ${ }^{103}$

U predmetu Uglešić protiv Hrvatske ${ }^{104}$ podnositeljica se žalila i na duljinu parničnog postupka pred domaćim sudovima. Međutim, Sud je zahtjev našao očito

101 Primjerice kada podnositelj predstavke propusti pružiti dokaz u prilog navoda iz predstavke.

102 Tako može postupiti kada se pitanje pravnih lijekova postavi pred njim kao prigovor države na dopuštenost zahtjeva, s jedne strane, i kao sam zahtjev koji pred njega iznosi pojedinac. Ovaj odnos Sud razmatra u slučaju Hartman protiv Češke (Hartman protiv Republike Češke, presuda od 10. srpnja 2003.) Protokolom 14. uz EK od 13. svibnja 2004. godine.

103 U toj fazi odluka se donosi većinom glasova članova vijeća i mora se obrazložiti. Npr. u predmetu Mladenić protiv Hrvatske podnositelj se žalio da mu je povrijeđeno pravo na pristup sudu, prigovarajući da je Ustavni sud obustavio postupak u povodu njegove ustavne tužbe, budući da je pogrešno smatrao da ju je on povukao. On, nadalje, navodi da je zbog obustave postupka pred Ustavnim sudom lišen mogućnosti da se ispitaju navodi o povredama njegovih ustavnih prava. Zahtjev je proglašen nedopuštenim kao očito neosnovan: «Sud smatra da se od podnositelja zahtjeva moglo razumno očekivati da Ustavnom sudu dostavi svoju novu adresu kako bi mogao primati pismena adresirana na njega, osobito s obzirom na to da je podnio ustavnu tužbu te je očekivao da će doći do daljnjeg dopisivanja s Ustavnim sudom. Vlasti se ne mogu smatrati odgovomima za sprečavanje njegovog pristupa sudu zato što podnositelj zahtjeva nije poduzeo nužne korake da osigura prijam svoje pošte te se tako nije mogao pridržavati zahtjeva Ustavnog suda da dostavi kopiju pobijane odluke».

104 Uglešić protiv Hrvatske, odluka o dopuštenosti zahtjeva od 11. listopada 2001. g., br. 50941/99. 
neosnovanim iz razloga: "Sud primjećuje kako je u razdoblju koje se uzima u obzir, iako se čini da predmet ne podrazumijeva nikakvu pravnu i činjeničnu složenost, postupak prvenstveno ometalo ponašanje podnositeljice zahtjeva". ${ }^{105}$ Zahtjevi u kojima se podnositelji pozivaju na povredu čl. 6. EK uglavnom se odnose na nezadovoljstvo ishodom postupka pri čemu se žale na pogrešno utvrđeno činjenično stanje ili nepravilnu ocjenu dokaza. ${ }^{106}$ Takvi zahtjevi odbacuju se kao očito neosnovani jer Sud nije Sud redovitog sudovanja već isključivo Sud koji se bavi pitanjem povrede ljudskih prava. U tom je smislu Komisija već vrlo rano utvrdila praksu prema kojoj je čl. 6. EK jedno isključivo postupovno jamstvo poštenog suđenja. ${ }^{107}$ Iscrpno obrazloženje koje sadrži pravilo da Sud nije sud redovitog sudovanja ("sud četvrte instance") dano je u djelomičnoj odluci o dopuštenosti zahtjeva Blečić protiv Hrvatske. ${ }^{108} \mathrm{U}$ onoj mjeri koliko se zahtjev podnositelja

105 Čini se da je Općinski sud u Zagrebu ročišta zakazivao u pravilnim vremenskim razmacima. Međutim, šest je ročišta odgođeno zbog izostanka podnositeljice zahtjeva. Nadalje, iako je podnositeljica zahtjeva od suda zatražila da izvrši očevid, dva je puta od suda tražila da odgodi zakazani posjet prostorima. Osim toga, dana 20. travnja 1999. sama je podnositeljica zahtjeva izričito obavijestila sud da odbija dalje sudjelovati u postupku. Odbijala je također i preuzimati bilo kakve obavijesti ili odluke koje joj je slao sud. Kao zaključak, Sud nalazi da se odugovlačenja do kojih je došlo nakon stupanja EK na snagu u odnosu na Hrvatsku mogu pripisati podnositeljici zahtjeva, Iz toga proizlazi da je ovaj prigovor očito neosnovan $\mathbf{i}$ da se mora odbiti u skladu s čl. 35., st. 3. i 4. EK».

106 U predmetu Ljubičić protiv Hrvatske (Ljubičić protiv Hrvatske, Odluka o dopuštenosti od 10. svibnja 2007., broj: 17338/05.) podnositeljica zahtjeva je 14. srpnja 1998. podnijela Zemljišnoknjižnom odjelu Općinskog suda u Zagrebu prijedlog radi uknjižbe prava vlasništva na novoizgrađenorn tavanu i garaži u zemljišne knjige. Podnositeljica zahtjeva je između ostalog podnijela zahtjev Sudu na temelju čl. 6. st. 1. EK zbog duljine postupka. Glede ponašanja podnositeljice zahtjeva, Sud primjećuje kako ona nije udovoljila pozivu Općinskog suda za dostavu potrebnih dokumenata te je tako onemogućila sudu da nastavi postupak po njenom prijedlogu. Sud stoga utvrđuje da je postupak ometan prvenstveno zbog ponašanja podnositeljice zahtjeva. Zaključno, Sud utvrđuje da je za zastoje u postupku isključivo odgovorna podnositeljica zahtjeva. Slijedi da je ovaj prigovor očito neosnovan te mora biti odbačen u skladu s čl. 35. st. 3. i 4. EK.

107 U predmetu Ryder protiv Ujedinjenog Kraljevstva Komisija navodi: "Kornisija nalazi da je objekt čl. 6. EK nužno ograničen na postupovna jamstva poštenog suđenja". Sud je primjerice u predmetima Stromberg protiv Danske i Pedersen protiv Danske naveo: «Sud podsjeća da je njegova jedina uloga u odnosu na čl. 6 . EK da ispituje navodne postupovne povrede u postupcima pred dornaćim sudovima te da na temelju toga, sagledavajući postupak, kao jedinstvenu cjelinu, ocijeni je li postupak bio vođen na način koji podnositelju osigurava pošteno/pravično suđenje». Stromberg protiv Danske, Odluka o dopuštenosti od 20. lipnja 2002., broj: 57211/00. Pedersen protiv Danske, Odluka o dopuštenosti od 12. lipnja 2003., broj: 68693/01.

$108 \mathrm{U}$ konkretnom predmetu Sud ne nalazi da bi bilo što ukazivalo da je ocjena činjenica i dokaznog materijala od strane redovitih sudova bila protivna čl. 6. EK. Podnositeljica je bila u mogućnosti prezentirati argumente pred sudovima, osporavati navode protivnika, svi bitni dokazi bili su izvedeni u postupku, u prvom stupnju provedena je javna rasprava te su odluke sudova bile zadovoljavajuće obrazložene. Sud također primjećuje da je podnositeljica bila u mogućnosti uložiti žalbu na prvostupanjsku odluku, kao i reviziju pred Vrhovnim sudom. U tim okolnostima Sud nalazi da predmetni zahtjev ne ukazuje ni na koji način na povredu prava na pošteno suđenje zajamčenog čl. 6. EK. Slijedi da je taj dio zahtjeva očito neosnovan 
odnosi na ocjenu dokaza i ishod postupka pred domaćim sudovima, Sud naglašava da je njegova uloga, prema čl. 19. EK, osigurati poštivanje prava zajamčenih EK. Posebno ističe da uloga Suda nije da ispituje jesu li činjenično stanje pogrešno utvrdili domaći sudovi niti je li došlo do pogrešne primjene prava, osim u mjeri u kojoj su takve pogreške dovele do povrede prava zajamčenih EK. ${ }^{109}$

\subsection{Zahtjev koji predstavlja zlouporabu prava na podnošenje zahtjeva}

Članak 35. st. 3. EK daje ovlast Sudu da proglasi neprihvatljivom pojedinačnu predstavku kojom se vrši zlouporaba prava na podnošenje zahtjeva. ${ }^{737}$ Zahtjevom koji podnosi Sudu podnositelj ne smije zloupotrijebiti to svoje pravo. Međutim, ovaj razlog nedopuštenosti zahtjeva se iznimno rijetko javlja u odlukama Suda. To je vjerojatno zbog činjenice da je vrlo teško ustanoviti zlouporabu, pošto se ne mogu lako ustanoviti motivi podnositelja, u svakom slučaju ne u raznim fazama ispitivanja. Ovdje se prije svega misli na zahtjeve u kojima pojedincu nije cilj zadovoljenje pravde i poštovanje ljudskih prava, nego publicitet i propaganda. Zahtjev koji navodno nema nikakvog pravnog osnova, i koji je podnesen iz propagandnih razloga, ne mora se odbiti kao zahtjev koji predstavlja zlouporabu prava na podnošenje zahtjeva, osim ako nije sasvim jasno zasnovan na netočnim izjavama ili činjenicarna. ${ }^{110} \mathrm{Ne}$ isključuje se mogućnost da i zahtjevi država budu odbijeni, ali na temelju općeg pravnog principa da se pravo pokretanja pred međunarodnirn tijelom ne smije zlouporabiti, mada ne treba pretpostaviti da će $u$ praksi olako doći do takvog zaključka. Sud će odbaciti svaki takav zahtjev i takva odluka može biti donesena u bilo kojem stadiju postupka. ${ }^{111}$

te mora biti odbačen sukladno čl. 35. st. 3. i 4. EK». Odluka o dopuštenosti od 6. prosinca 2001., broj 56773/00.

109 U čl. 6. EK koji jamči pravo na pošteno suđenje, nisu propisana nikakva posebna pravila o dokazivanju u postupcima pred sudovima, te je stoga ova materija prvenstveno stvar regulacije domaćeg zakonodavstva, odnosno domaćeg sudovanja. Vidjeti presude Schenk protiv Austrije, 12. srpanj 1988., Serija A br. 140, str. 29, §§ 45-46 i Garcia Ruiz protiv Španjolske, br. 30544/96, Zbirka presuda i oduka 1999-1, § 28.

110 Zlouporaba prava na podnošenje zahtjeva najčešće se manifestira kao svjesno iznošenje neistinitih ili neosnovanih optužbi, uporabu uvredljivog i pogrdnog jezika za vladu protiv koje je zahtjev upućen, te zlonamjerno kršenje pravila povjerljivosti u sudskom postupku. Taj pojam korišten je i kada podnositelj zahtjeva nije odgovorio na nekoliko upita u vezi s razmatranjem svog zahtjeva, i kada je, na primjer, davao uvredljive izjave na račun predstavnika tužene države. Namjemo prikrivanje ili izostavljanje relevantnih informacija od Suda, falsificiranje relevantnih dokumenata i svjesno iznošenje netočnih činjenica također može utjecati na odluku Suda da zahtjev proglasi neprihvatljivim. Činjenica da podnositelj zahtjeva nije obavijestio Komisiju o tome da je, nakon podnosenja predstavke, na temelju istih činjenica pokrenuo postupak pred domaćim sudom, nije se smatrala zlouporabom prava na pritužbu.

111 Vidi Perić, M., op. cit. (bilj. 88.), str. 71-71. 


\section{ZAKLJUČAK}

Suvremeni razvoj prava i sloboda rezultirao je lakoćom donošenja, odnosno usvajanja mnogobrojnih deklaracija o slobodama i pravima, ali i čestim kršenjem i nepoštovanjem tih istih sloboda i prava. Međutim, nije dovoljno imati dobre zakone, usklađene s međunarodnim standardima, već je važno osigurati njihovo ostvarivanje u praksi odnosno zaštitu prava i slobode pojedinca bez razlike u pristupu. Smatramo posebno značajnirn provoditi edukaciju stanovništva kako bi se u dovoljnoj mjeri razvila svijest o ljudskim pravima i temeljnim slobodama $\mathrm{i}$ potrebi njihovog poštovanja u praksi. Osobito je važno razvijati svijest kod svih onih koji svakodnevno provode zakone u praksi, izvršnu vlast i pravosudna tijela, o značaju jednakog pristupa za sve u primjeni zakona i zaštiti temeljnih ljudskih prava na jednak način prema svima, kroz stručna usavršavanja, ali i stvaranjem takvog zakonodavnog okvira gdje nije moguće drukčije postupanje, odnosno u kojem će svako drugačije postupanje biti sankcionirano. Treba težiti da standardi zaštite iz EK postanu realnost u Republici Hrvatskoj i osigurati minimalne ekonomske preduvjete da bi se oni realizirali u praksi.

Da bi se mogao podnijeti zahtjev Sudu potrebno je ispuniti određene uvjete. Sud je strogo formalni sud koji vrlo temeljito ispituje uvjete dopuštenosti. Statistika suda jasno pokazuje da se većina zahtjeva odbacuje upravo radi neispunjavanja tih uvjeta. Uvjeti dopuštenosti služe Sudu kao filter kojim se nastoji zaštititi od toga da postane neka vrsta suda četvrtog stupnja. Upravo stoga faza ispitivanja dopuštenosti često je i odlučujuća za sudbinu zahtjeva, posebice zato jer se odluka Suda o nedopuštenosti ne može ni na koji način pobijati. ${ }^{12}$ Međutim, iako je odluka Suda ograničena na ocjenu formalnih uvjeta dopuštenosti njezin je učinak daleko značajniji. Nju ne treba promatrati samo u kontekstu procesne odluke suda kojom su odbačeni prigovori tužene države i kojom se Sud proglasio nadležnim za odlučivanje o meritumu predmeta. Naime, bez obzira na to kakva će biti presuda, svojom odlukom Sud je napravio važan iskorak u području zaštite ljudskih prava. Da bi se shvatilo značenje odluke potrebno je imati na umu karakter postupka pred Sudom. Sud ispituje pojedinačne slučajeve i njegove presude nemaju snagu obvezujućeg presedana, ali su postavile standarde zaštite ljudskih prava, i to glede sadržaja pojedinog prava i granica do kojih je državi dopušteno miješanje u pojedino pravo. Države protiv kojih su donesene presude morale su mijenjati svoje zakone, ustave i pravnu praksu. U nekim od svojih presuda Sud je dao revolucionarne interpretacije ljudskih prava s dalekosežnim učincima. Možemo zaključiti da je poznavanje pravnih standarda koje državama ugovornicama naznačuje praksa Suda iznimno važno za sve koji sudjeluju u pravosudnom sustavu pojedine države ugovornice. Jedini način da se ti standardi upoznaju i primjene je proučavanje prakse Suda.

Međutim, efikasna zaštita ljudskih prava osigurava se prvenstveno na temeljnoj razini, u tijelima uprave, sudovima i odvjetničkirn uredima. Suradnja domaćih

112 Vidi Maričić, D., Odluka Europskog suda za ljudska prava o dopuštenosti zahtjeva, Informator, broj: 5240 - godina LII, 2004., str. 3. 
sudova, osobito Ustavnog suda, sa Sudom u zaštiti prava čovjeka sastavni je dio cjelovitog sustava zaštite ljudskih prava. Kad bi sudovi primjenjivali EK na način kako to čini Sud i češće se pozivali na njegove presude, to bi svakako predstavljalo važan iskorak u razvoju zaštite ljudskih prava. Stoga je iznimno važno poznavanje i praćenje prakse Suda u svim institucijama u kojima dolazi do interakcije između pojedinca i vlasti. Idealno bi bilo unaprijed uočiti situacije koje su u suprotnosti s EK i usklađivati i zakonodavstvo i praksu, a ne čekati da Sud u konkretnom predmetu utvrdi da je došlo do povreda EK. 
Summary

\section{THE CONDITIONS OF ADMISSIBILITY OF THE APPLICATION TO THE EUROPEAN COURT OF HUMAN RIGHTS}

This paper analyzed the conditions of admissibility of the application to the European Court of Human Rights stating the specific examples and decisions about admissibility adopted by the Court that in order to assist applicants that, due to formal flaws in the proceedings, do not lose their ability to realize their rights in the court. The author seeks to emphasize the importance of possibility of proceedings in the court to realize fundamental human rights and freedoms of the citizens of Croatia. Conditions of admissibility of the application are regulated in Art. 33, Art. 34 and Art. 35 of European Convention for the Protection of Human Rights and Fundamental Freedoms and most requests are rejected due to their failure in those requirements. The admissibility stage of testing is often decisive for the fate of the request, the more so as the decision of inadmissibility cannot be disputed in any way.

Key words: European Convention for the Protection of Human Rights and Fundamental Freedoms, the European Court of Human Rights, the application, the conditions of admissibility.

\section{Zusammenfassung}

\section{BEDINGUNGEN DER EINLEITUNGSZULÄSSIGKEIT EINES PROZESSES VOR DEM EUROPÄISCHEN GERICHTSHOF FÜR MENSCHENRECHTE IN STRASBOURG}

In dieser Arbeit werden die Bedingungen der Einleitungszulässigkeit vor dem Europäischen Gerichtshof für Menschenrechte bearbeitet, mit Anführung einiger Beispiele, bzw. Beschlüsse von der Zulässigkeit, die dieser Gerichthof gebracht hat, um den Antragstellern zu helfen, nicht wegen Formfehlern während der Prozesseinleitung die Möglichkeit ihrer Rechteerzielung vor dem Gericht nicht verlieren. Die Autorin bemüht sich auf die Bedeutung der Möglichkeit der Prozesseinleitung vor diesem Gericht für die Erzielung der Grundmenschenrechte und Freiheiten der Bürger von Republik Kroatien hinzuweisen. Die Bedingungen der Zulässigkeit der Antragsstellung wurden mit Art. 33, Art. 34 und Art. 35 der Europäischen Konvention zum Schutz der Menschenrechte und Grundfreiheiten normiert. Die Mehrheit der Anträge wird gerade wegen der Nichterfüllung dieser 
Bedingungen abgeworfen. Die Zulässigkeitserfragung ist für den Antragschicksal oft von entscheidender Bedeutung, desto mehr weil der Beschluss der Nichtzulässigkeit auf keine Weise abgeworfen werden kann.

Schlüsselwörter: Europäische Konvention zum Schutz der Menschenrechte und Grundfreiheiten, Europäischer Gerichtshof für Menschenrechte, Antrag, Zulässigkeitsbedingungen.

\section{Riassunto}

\section{CONDIZIONI DI AMMISSIBILITÀ DELL'AVVIO DEL PROCEDIMENTO DINNANZI ALLA CORTE EUROPEA PER I DIRITTI UMANI DI STRASBURGO}

Nel presente lavoro si analizzano le condizioni di ammissibilità di adire la Corte europea dei diritti dell'uomo con l'indicazione di alcuni esempi, ovvero di alcune decisioni circa l'ammissibilità prese da tale Corte, al fine di aiutare i ricorrenti a non perdere, a causa di lacune formali al momento dell'avvio della procedura, la possibilità di realizzare i propri diritti dinnanzi a tale Corte. L'autrice cerca di porre in rilievo la portata della possibilità di avvio della procedura dinnanzi a tale corte per la soddisfazione dei diritti e delle libertà fondamentali dell'uomo dei cittadini della Repubblica di Croazia. Le condizioni di ammissibilità dell'avvio della procedura sono regolate agli articoli 33, 34 e 35 della Convezione europea per la salvaguardia dell'uomo e delle libertà fondamentali. La maggiore parte dei ricorsi viene rigettata proprio a causa del mancato rispetto di tali condizioni. L'analisi dell'ammissibilità sovente è determinante per il destino del ricorso; a maggiore ragione in quanto la decisione di inammissibilità non può in alcun modo essere impugnata.

Parole chiave: Convenzione europea per la salvaguardia dei diritti e delle libertà fondamentali, Corte europea dei diritti dell'uomo, ricorso, condizioni di ammissibilità. 